\title{
EPSL
}

Earth and Planetary Science Letters 125 (1994) 17-37

\section{Isotopic constraints on the production rates, crystallisation histories and residence times of pre-caldera silicic magmas, Long Valley, California}

\author{
Gareth R. Davies ${ }^{\mathrm{a}, 1}$, Alex N. Halliday ${ }^{\mathrm{a}}$, Gail A. Mahood ${ }^{\mathrm{b}}$, Chris M. Hall ${ }^{\text {a }}$ \\ ${ }^{a}$ Department of Geological Sciences, University of Michigan, Ann Arbor, MI 48109-1063, USA \\ ${ }^{b}$ Department of Geological and Environmental Sciences, Stanford University, Stanford, CA 94305-2115, USA
}

Received 3 April 1992; revision accepted 19 May 1994

\begin{abstract}
Pre-caldera high-silica rhyolites of Glass Mountain, California erupted episodically from $2.1 \mathrm{Ma}$ until the catastrophic eruption of the Bishop Tuff at $0.74 \mathrm{Ma}$. The lavas are extremely evolved, with $\mathrm{Rb} / \mathrm{Sr}$ ratios between 128 to 3640 , the latter being the highest recorded from a volcanic rock. Glass separates from pre-1.2 Ma lavas define two geographically controlled $\mathrm{Rb}-\mathrm{Sr}$ isochrons. Lavas adjacent to the current caldera rim define an isochron age of $2.047 \pm 0.013 \mathrm{Ma}$ with an initial ratio of $0.7063 \pm 2$, and lavas more distant from the caldera define an isochron of $1.894 \pm 0.013 \mathrm{Ma}$ with the same initial ratio. The isochrons are consistent with the magmas forming within $26 \mathrm{ka}$, which implies a minimum magma production rate of $0.75 \times 10^{-3} \mathrm{~km}^{3} / \mathrm{yr}$ over this period. $\mathrm{New}^{40} \mathrm{Ar}-{ }^{39} \mathrm{Ar}$ ages on sanidine and biotite have established that lavas defining each isochron were erupted over a long time interval, the isochron ages being up to $360 \mathrm{ka}$ older than the youngest eruption age.

$\mathrm{Rb}-\mathrm{Sr}$ isotope data are reported for minerals from three lavas with eruption ages of $1.990 \pm 0.012,1.866 \pm 0.014$ and $1.686 \pm 0.011 \mathrm{Ma}$. Petrographically early apatite inclusions in biotite and biotite inclusions in feldspar and quartz have glass-mineral $\mathrm{Rb}$-Sr ages that are indistinguishable from the relevant regional isochron. Sr diffusion in feldspar is slow at the magmatic temperatures inferred for Glass Mountain rhyolites $\left(\sim 700^{\circ} \mathrm{C}\right)$ such that over $0.5 \mathrm{Ma}$ the cores of large feldspars $(>1 \mathrm{~mm}$ ) will retain $>99.9 \%$ of their original $\mathrm{Sr}$. The cores of sanidine and plagioclase yield glass-mineral ages that are up to $300 \mathrm{ka}$ older than eruption ages. Feldspar rim ages for two samples are indistinguishable from eruption ages. The rims of sanidines and plagioclases from the third sample are 110 and 280 $\mathrm{ka}$ older than the eruption age and 180 and $20 \mathrm{ka}$ younger than the cores. These mineral age data probably reflect the combination of extended periods of mineral growth and partial isotopic exchange with the host liquid during protracted residence in a magma reservoir. However, the $\mathrm{Ar}$ and $\mathrm{Sr}$ isotopic data for biotite phenocrysts are consistent with the presence of a significant component that is recycled from earlier magmatic pulses.

Due to the extreme $\mathrm{Rb} / \mathrm{Sr}$ ratios of the rocks and minerals it is possible to very precisely resolve the time difference between the formation of different phases, assuming that they crystallised from the same host magmas (e.g., $\left.T_{\text {plagioclase }}-T_{\mathrm{Fe}-\mathrm{Ti} \text { oxide }}=6.8 \pm 0.1 \mathrm{ka}\right)$ and the maximum time taken to form a phase (e.g., $T_{\text {plagioclase core }}-$ $T_{\text {plagioclase rim }}=32.3 \pm 0.2 \mathrm{ka}$ ). The timescale for mineral growth is shorter in the chemically more evolved and
\end{abstract}

[RvdV]

1 Now at: Faculteit der Aardwetenschappen, Vrije Universiteit, 1081 HV Amsterdam, The Netherlands 
crystal-poor lavas, consistent with these magmas having resided at higher levels in the magma chamber with shorter residence times and being more liable to extrusion. By using mineral inclusion relationships, average mineral growth rates are estimated to be between $7 \times 10^{-13}$ and $8 \times 10^{-14} \mathrm{~cm} / \mathrm{s}$. These values are significantly lower than those measured in basaltic systems and probably reflect a combination of the slow cooling ratc of the Glass Mountain magma chamber(s) and the highly polymerised nature of high-silica magmas.

\section{Introduction}

Rates of magma differentiation and residence times of silicic magmas in crustal magma chambers have been estimated from observations of the volume and periodicity of eruptive products at individual volcanic centres $[1,2]$ and by modelling the thermal and fluid dynamic properties of magmas [3]. $\mathrm{Rb} / \mathrm{Sr}$ ratios of many high-silica rhyolites are sufficiently high $\left(>10^{3}\right)$ that the $\mathrm{Sr}$ isotope compositions can be used to place direct limits on the time span of magma differentiation [4,5]. In certain instances, periods of the order of $10^{3}$ yr can be accurately measured with current techniques. Furthermore, if the phenocrysts are cogenetic with their host glasses, the timing of crystal growth can be determined even more precisely and growth rates can be deduced from core-rim disequilibria, provided re-equilibration is slow relative to change in $\mathrm{Sr}$ isotope composition by in-situ decay. Current estimates of crystal growth rates, which range from $10^{-6}$ to $10^{-11}$ $\mathrm{cm} / \mathrm{s}$, have been determined experimentally, from crystal size distributions and from the the observation of rapidly cooling 'basaltic' lava lakes [6]. To date, there is little information about the growth rates of minerals in silicic systems. In this paper, the $\mathrm{Rb}-\mathrm{Sr}$ isotope systematics of pristine high-silica rhyolite lavas from Glass Mountain, California are used to place limits on the timing of differentiation, the production rates of the magmas, phenocryst growth rates and the residence time of magmas prior to eruption.

\section{Glass Mountain Lavas}

Glass Mountain is located on the northeastern margin of the Long Valley caldera in east-central California and consists of over $50 \mathrm{~km}^{3}$ of high- silica rhyolite lavas and pyroclastic deposits (Fig. 1) [7]. There are at least 50 lava flows, many of which locally contain pristine glass. Individual lava domes have volumes between 0.1 and $5 \mathrm{~km}^{3}$ (Fig. 1). Rhyolitic volcanism began at $2.1 \mathrm{Ma}$ and continued episodically until the caldera-forming eruption of the Bishop Tuff at $0.74 \mathrm{Ma}$ [7]. The lavas of Glass Mountain are very evolved [7,8], with low phenocryst contents of typically less than $3 \%$ and comprising quartz, sanidine, plagioclase and biotite. Lavas erupted prior to $1.2 \mathrm{Ma}$ tend to be smaller in volume with more evolved and varied compositions than the younger Glass Mountain lavas, which are slightly less evolved than the earliest Bishop Tuff. The Nd isotope compositions are more radiogenic in the younger (post-1.2 Ma) lavas, marking the formation of a new magma system that eventually produced the Bishop Tuff magma $500 \mathrm{ka}$ later $[4,5,8,9]$.

In an earlier study of Glass Mountain rhyolites, Halliday et al. [4] reported two $\mathrm{Rb}-\mathrm{Sr}$ isochrons among the pre-1.2 Ma lavas that were delimited by the geographical distribution of the lavas. A $2.09 \pm 0.06 \mathrm{Ma}$ isochron was defined by the lavas closest to the present caldera, whereas a $1.90 \pm 0.02 \mathrm{Ma}$ was determined for lavas further away. Halliday et al. [4] argued that the preservation of these isochronal relationships in magmas erupted as lavas at a much later time (as late as 1.35 Ma [7]) implied that magma formation occurred in two discrete events and that the magmas subsequently remained in a stable, stratified state for up to $700 \mathrm{ka}$. Christensen and DePaolo [5] also argued for a prolonged evolution for the Bishop Tuff magma system on the basis of $\mathrm{Sr}$ isotope differences between sections of the Bishop Tuff and $\mathrm{Sr}$ isotope disequilibrium between feldspars and their host glasses. Sparks et al. [10] pointed out that there are thermal constraints imposed upon the state of a magma chamber if it 


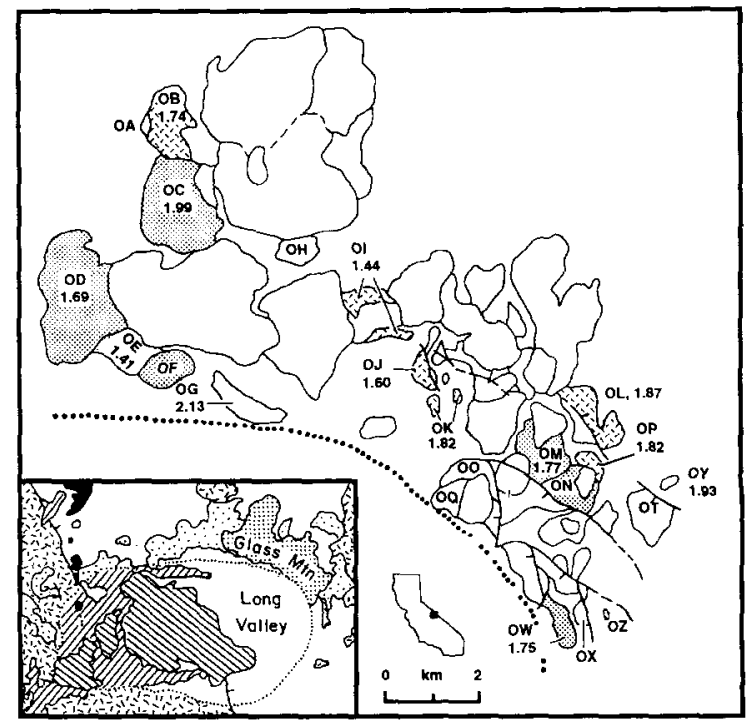

Fig. 1. Sketch map of Glass Mountain modified from Metz and Bailey [39]. Prefix ' $O$ ' is for older, pre-1.2 Ma lavas (individual flow units distinguished by letters). Unmarked area on map represents tuffs of Glass Mountain and Bishop Tuff together with caldera lake sediments and Recent surficial deposits. Inner Lavas which lie on $\mathrm{Rb}-\mathrm{Sr}$ isochron of age $2.047 \pm 0.013 \mathrm{Ma}$ are represented by stipple pattern. Outer Lavas which lie on $\mathrm{Rb}-\mathrm{Sr}$ isochron of age $1.894 \pm 0.013 \mathrm{Ma}$ are represented by dashed pattern.

were to exist for $700 \mathrm{ka}$ and reinterpreted the data in terms of remelting recently crystallised granites deep within the crust. Mahood [11] modified this second model and proposed remelting or 'defrosting' of the crystallised margins of the high-level Long Valley magma chamber(s) to explain the $\mathrm{Rb}-\mathrm{Sr}$ isochrons. Halliday [12] pointed out the physical problems of repeatedly remelting a source or magma chamber and still preserving a $\mathrm{Rb}-\mathrm{Sr}$ isochron defined by low-Sr liquids.

The aims of this study of the Glass Mountain Older Lavas were to confirm that the differences between the $\mathrm{Rb}-\mathrm{Sr}$ isochrons and $\mathrm{K}-\mathrm{Ar}$ eruptive ages were valid $[4,7,12]$, test the hypothesis of protracted magma residence by using the $\mathrm{Rb}-\mathrm{Sr}$ isotope systematics of minerals to constrain the crystallisation history and to provide precise magma production and crystal growth rates for high-silica rhyolites.

\section{Petrography}

Samples from three lavas (OD, OC and OL of [8]) were examined in detail. Quartz, biotite, sanidine and plagioclase are the dominant phenocryst phases. Small euhedral biotites $(<0.1 \mathrm{~mm})$ are included as cores to quartz but are found throughout sanidine and plagioclase grains. Apatite, zircon, Fe-Ti oxides and allanite are common inclusions in biotite but are rare in other phases. Plagioclase inclusions are common in sanidine and both feldspars are found included in quartz. Biotite contains neither quartz nor feldspar inclusions, implying that in the studied samples biotite crystallised early and quartz later. Crystallisation of minor phases appears to have begun early; the presence of large discrete grains in some lavas [8] implies that their crystallisation was long-lived. Feldspar phenocrysts are euhedral, indicating equilibrium crystallisation from a melt with no evidence of resorption.

Microprobe analyses of hand-picked separates demonstrate that the phenocrysts are only modestly zoned in major element composition $[8,13]$. However, both plagioclase and sanidine invariably have a thin (ca. $0.1 \mathrm{~mm}$ ) overgrowth of sodic plagioclase. Crushing and sieving of samples tended to detach part or all of the overgrowths. TEM studies demonstrate that this overgrowth is poorly crystalline and probably formed under conditions of high vapour pressure [14]. Similar overgrowths are found throughout the Bishop Tuff such that in hand specimen many feldspars appear altered despite having a gem-quality core $[13,14]$. Typically feldspar grains are $1-5 \mathrm{~mm}$ in diameter, although larger feldspar grains with a maximum size of $1.0 \mathrm{~cm}$ were recorded in each sample $(<0.1 \%$ of the population). Microdrilling was carried out on the largest $(>5 \mathrm{~mm})$ grains that retained the sodic plagioclase overgrowth. The representative mineral analyses of all phases are reported elsewhere [8].

Some of the Glass Mountain lavas contain a sparse xenocrystic population probably derived from local basement rocks [8]. Partially altered albite and Ca-poor anorthoclase were observed in bulk separates from samples OC and OL $(<0.1 \%$ of each of the feldspar populations). Very rare 
pale brown biotites were observed in sample OC ( $<0.01 \%$ of biotite population). These xenocrysts have ragged or rounded margins and were excluded from the analysed material during handpicking. Microprobe analyses of the xenocrystic minerals generally yielded poor totals, confirming the petrographic observation that they were partially altered. With the exception of the rare xenocrysts, biotite compositions are homogeneous in the three studied samples $[8,13]$. Sanidine and plagioclase compositions were also found to be relatively homogeneous. For example, the orthoclase content of the three sanidine populations
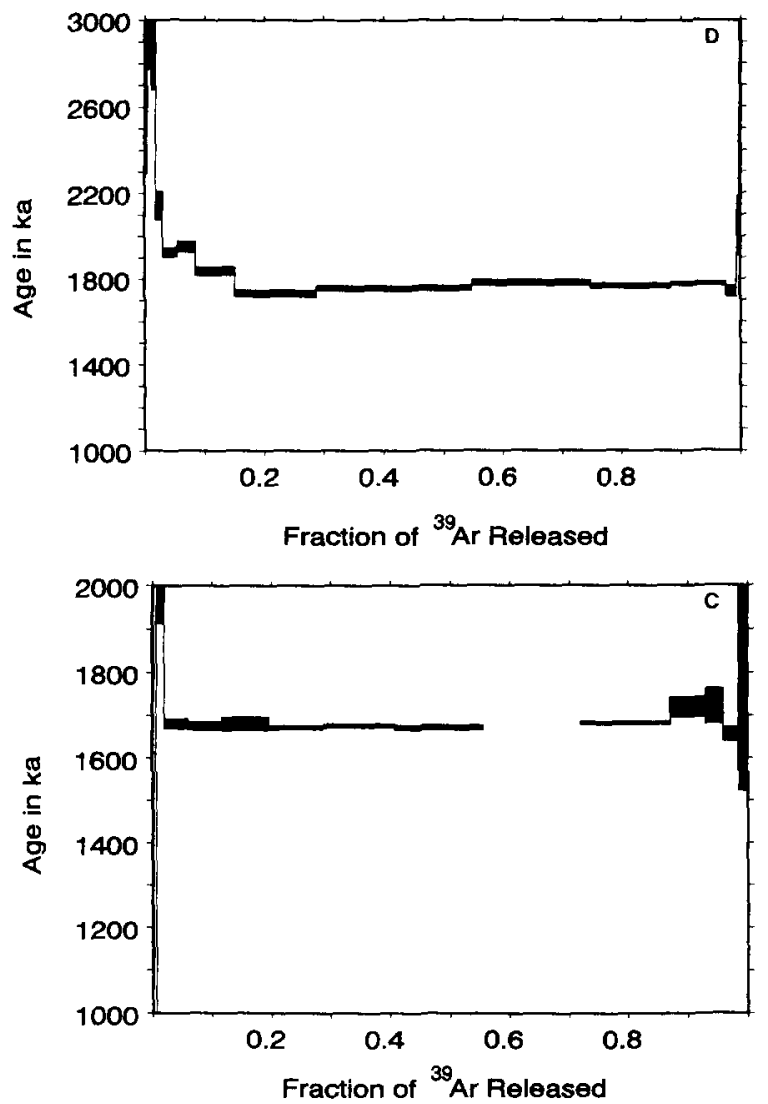

studied here varied between $\mathrm{Or}_{52}$ and $\mathrm{Or}_{61}(N>$ 15 for each sample [13]).

\section{Techniques}

After hand-picking, the mineral and glass samples were repeatedly cleaned by ultrasonic agitation in acetone and water. Multiple quartz fractions were separated according to their inclusion content. A composite of biotite inclusions was extracted from a mixed quartz-sanidine-plagioclase population of OD. Similarly two apatite com-
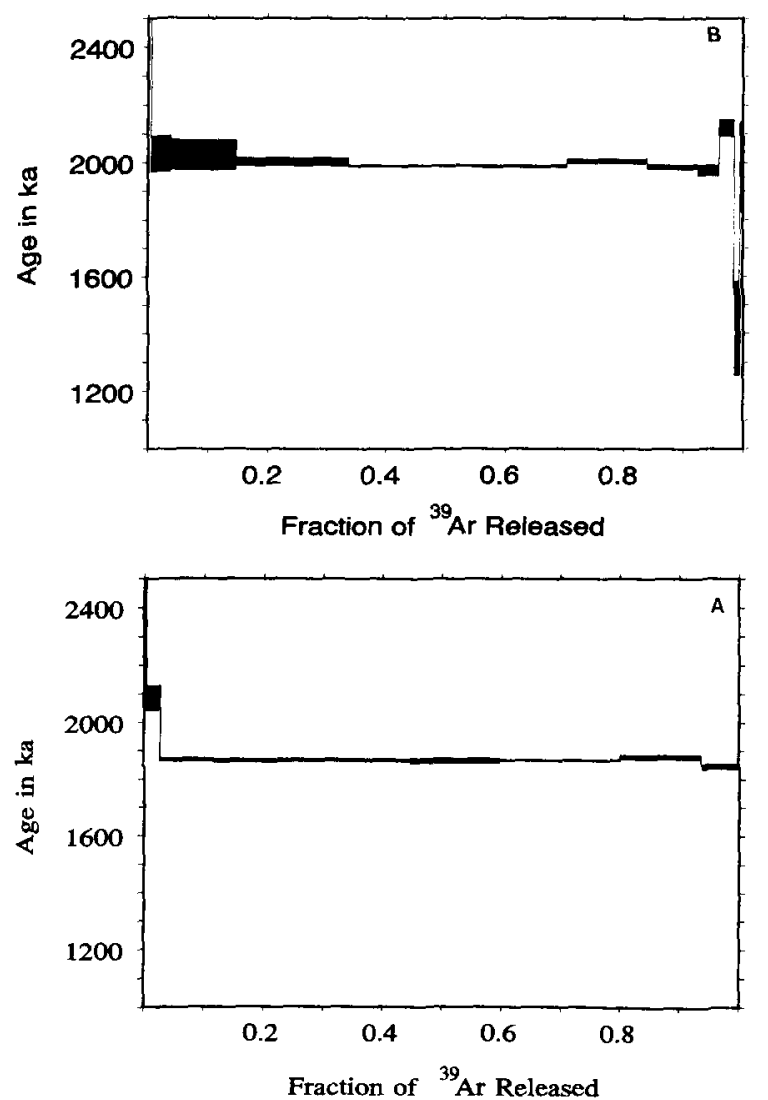

Fig. $2 .{ }^{40} \mathrm{Ar}-{ }^{39} \mathrm{Ar}$ step release spectra from (A) sanidine composite from lava OD. Total degas age is $1.704 \pm 0.016 \mathrm{Ma}$. The data yield a plateau age of $1.691 \pm 0.014 \mathrm{Ma}$ on $83.2 \%$ of the gas and an ${ }^{36} \mathrm{Ar} /{ }^{40} \mathrm{Ar}$ vs. ${ }^{39} \mathrm{Ar} /{ }^{40} \mathrm{Ar}$ isochron age of $1.686 \pm 0.011 \mathrm{Ma}$. One step was not analysed due to an electrical malfunction in the magnet power supply. The gas fraction became very fractionated before analysis was possible but the volume of gas is known. (B) Biotite composite from lava OD. Total degas age is $1.815 \pm 0.019$ $\mathrm{Ma}$ with a significant inherited argon component. The data yield an ${ }^{36} \mathrm{Ar} /{ }^{40} \mathrm{Ar}$ vs. ${ }^{39} \mathrm{Ar} /{ }^{40} \mathrm{Ar}$ age of $1.688 \pm 0.038 \mathrm{Ma}$. (C) Sanidine composite from lava OC. Total degas age is $1.976 \pm 0.091 \mathrm{Ma}$. The data yield a plateau age of $1.999 \pm 015 \mathrm{Ma}$ on $95.4 \%$ of the gas and an isochron age of $1.990 \pm 0.012 \mathrm{Ma}$. (D) Sanidine composite from lava OL. Total degas age is $1.895 \pm 0.017 \mathrm{Ma}$. The data yield a plateau age of $1.867 \pm 0.005 \mathrm{Ma}$ on $77.4 \%$ of the gas and an isochron age of $1.866 \pm 0.014 \mathrm{Ma}$. 


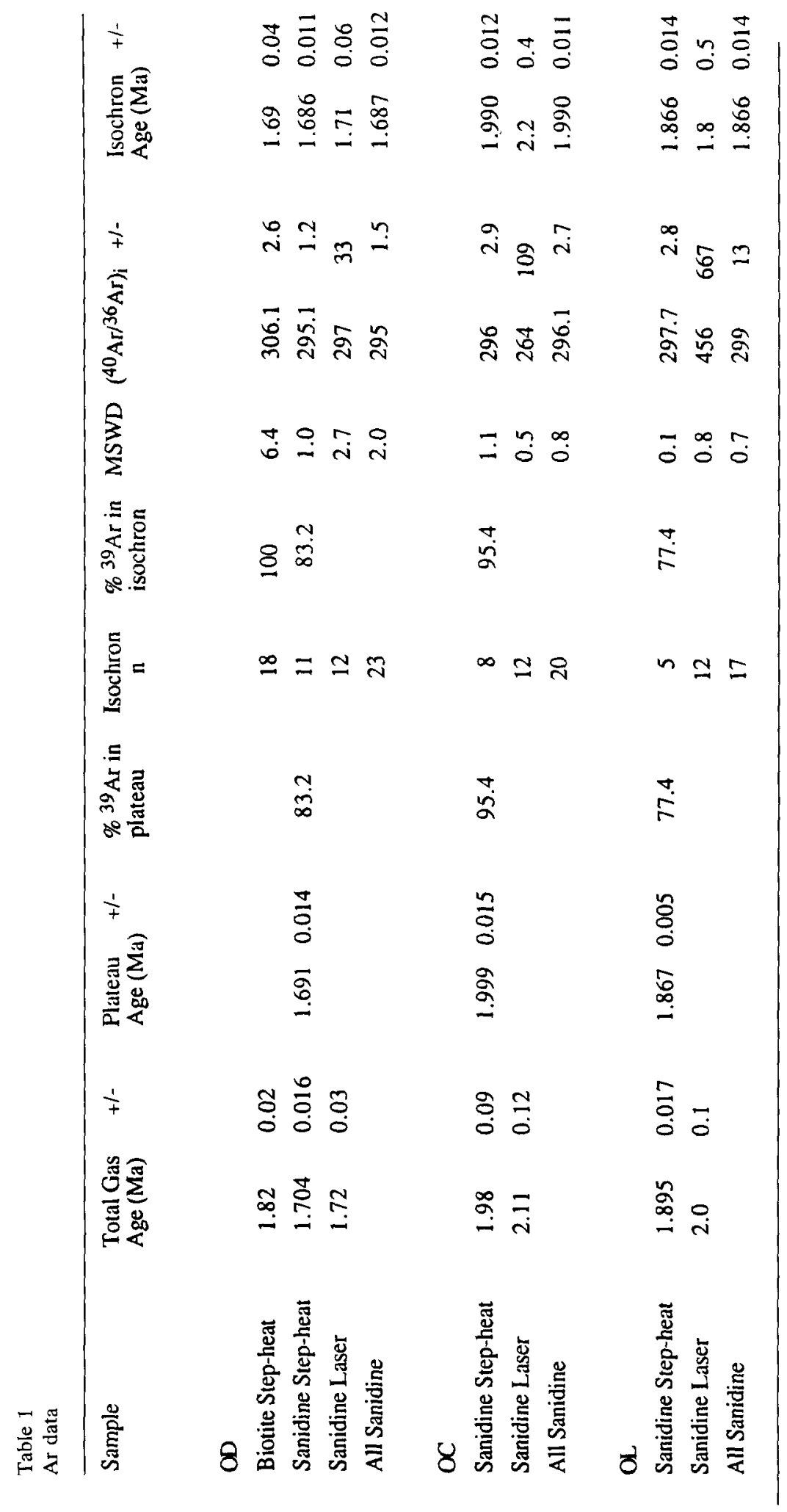


posites (ten and fifteen grains) were extracted from inclusion-bearing biotites in lava OD. The reproducibility of $\mathrm{Rb} / \mathrm{Sr}$ ratios over the two-year period of this study was found to be better than $0.5 \%$, but a conservative value of $1 \%$ is used in all age calculations. Isotope analyses of feldspars were confined to the largest grains in each sample. To check for homogeneity, multiple bulk and individual feldspar grains were analysed. Bulk feldspar separates were hand-picked to ensure they did not contain translucent plagioclase overgrowths. In addition, cores and translucent overgrowths of the largest feldspar grains were sampled using a microdrill. Bulk sanidine separates for ${ }^{40} \mathrm{Ar}-{ }^{39} \mathrm{Ar}$ analysis were prepared as above and each separate split $10 \%$ and $90 \%$, for laser-probe and step-heating respectively.

$\mathrm{Sr}-\mathrm{Nd}-\mathrm{Pb}$ isotope analyses were carried out at the University of Michigan following standard procedures [4]. A Sr blank was measured with every eleven samples. Nine Sr blank determinations ranged between 45 and $87 \mathrm{pg}$ and yielded ${ }^{87} \mathrm{Sr} /{ }^{86} \mathrm{Sr}$ ratios of $0.7156-0.7164$. The $\mathrm{Sr}$ isotope ratios of glasses were determined on relatively large samples $(50-75 \mathrm{mg}$ ). Blank corrections were $<0.3 \%$ and were ignored for all samples except OL, for which a correction of $1.7 \%$ was applied. All isotopic measurements were performed on V.G. Sector multicollector thermal ionisation mass spectrometers. The average ${ }^{87} \mathrm{Sr} /{ }^{86} \mathrm{Sr}$ for NIST SRM 987 was $0.710259 \pm 12(N>100)$ and the average ${ }^{143} \mathrm{Nd} /{ }^{144} \mathrm{Nd}$ for the La Jolla $\mathrm{Nd}$ standard was $0.511857 \pm 6(N>100)$. All Pb isotope ratios were normalised using NIST SRM 981 with a fractionation factor of $0.11 \% / \mathrm{amu}$.

Step-heating ${ }^{40} \mathrm{Ar}-{ }^{39} \mathrm{Ar}$ analyses were performed at the University of Michigan using a Mass Analyser Products 215 mass spectrometer equipped with a Faraday cup and an electron multiplier (gain $\approx 8000$ ). Each step included 20 min of heating and $5 \mathrm{~min}$ for clean-up. Typical blanks at mass 40 were about $2 \times 10^{-11} \mathrm{ml} \mathrm{STP}$ at $900^{\circ} \mathrm{C}$ and about $1.4 \times 10^{-9} \mathrm{ml} \mathrm{STP}$ at $1700^{\circ} \mathrm{C}$. The ages for all of the Michigan analyses are based upon an age of $520.4 \mathrm{Ma}$ for standard hornblende MMhb-1. Laser fusion ${ }^{40} \mathrm{Ar}-{ }^{39} \mathrm{Ar}$ analyses were performed at the University of Toronto [15]. Ages calculated for these samples are based on an age for standard biotite $4 \mathrm{~B}$ of 17.25 Ma, which in turn is referenced to an age of $1071 \mathrm{Ma}$ for standard hornblende $3 \mathrm{gr}$.

\section{Isotopic data}

\section{1. ${ }^{40} \mathrm{Ar-}{ }^{39} \mathrm{Ar}$ ages}

The ${ }^{40} \mathrm{Ar}-{ }^{39} \mathrm{Ar}$ results are presented in Fig. 2 and summarised in Table 1 ( $2 \sigma$ errors are reported throughout this paper). The plateau ages and the step-heating and laser total gas ages are in agreement, indicating little excess ${ }^{40} \mathrm{Ar}$ in the sanidines. All isochrons for plateau fractions are compatible with initial Ar with an atmospheric isotopic composition (Table 1). For all three samples studied (OC, OD and OL), the laser-generated single crystal ages and the plateau fractions of the step-heating runs define an isochron (Table 1). The best estimates for the eruption ages of these units are $1.990 \pm 0.012 \mathrm{Ma}(\mathrm{OC}), 1.686 \pm$ $0.011 \mathrm{Ma}(\mathrm{OD})$ and $1.867 \pm 0.005 \mathrm{Ma}(\mathrm{OL})$. These ages are consistent with the available field relationships, which demonstrate that the rhyolite dome $\mathrm{OC}$ is older than adjacent domes (e.g., $\mathrm{OB}=1.74 \mathrm{Ma}$ ).

The biotite separate from OD yields a total fusion age which is significantly higher than that of the coexisting sanidine. The biotite's age spectrum is saddle-shaped, with a minimum at about $1.74 \mathrm{Ma}$, significantly older than the $1.69 \mathrm{Ma}$ age for the sanidine. However, an isochron fit through all eighteen biotite fractions yields an apparent age of $1.688 \pm 0.038 \mathrm{Ma}$, which is indistinguishable from the coexisting sanidine results. The apparent initial ${ }^{40} \mathrm{Ar} /{ }^{36} \mathrm{Ar}$ ratio was $306 \pm 3$ in the biotite, indicating that the mineral received a non-atmospheric component. The concordancy between the sanidine laser fusion ages (where many different grains are analysed individually) and the step-heating results for sanidine and biotite from the same rock provide powerful evidence against post-eruptive argon loss. The agreement with field relationships provides confirmation that these new ${ }^{40} \mathrm{Ar} /{ }^{39} \mathrm{Ar}$ ages accurately date the eruption of the lavas when the minerals last cooled below their Ar blocking tem- 
peratures. Nevertheless, there is evidence for a slight excess Ar component in the biotites, consistent with the $\mathrm{Rb}-\mathrm{Sr}$ evidence presented below indicating that some biotites may be recycled from earlier pulses of magma. In a previous study [7] K-Ar ages were reported for glass and sanidine from the same lava flows. Sample OC yields an age of $1.990 \pm 0.012 \mathrm{Ma}$ within error of the previous result $(1.92 \pm 0.10 \mathrm{Ma})$. The new analysis of sample OL $(1.867 \pm 0.005 \mathrm{Ma})$ is also within the uncertainties reported previously (1.56 and $1.63 \pm 0.30 \mathrm{Ma}$ ). In contrast, sample OD yields a plateau age of $1.686 \pm 0.011 \mathrm{Ma}$, which is significantly older than the previously reported ages of $1.35 \pm 0.20$ Ma from a sanidine composite and $1.33 \pm 0.20 \mathrm{Ma}$ from the felsite.

\subsection{Glass Rb-Sr isotope data}

$\mathrm{Rb} / \mathrm{Sr}$ ratios of rhyolite glasses from the Older Lavas at Glass Mountain range from 127.6 to 3637 (Table 2). The Rb contents of the rhyolite glasses are not exceptionally high (165-313 ppm), but the $\mathrm{Sr}$ contents are generally below $1 \mathrm{ppm}$. Sample OL has the lowest $\mathrm{Sr}$ content recorded from a volcanic glass $(0.069 \mathrm{ppm})$ and the highest
$\mathrm{Rb} / \mathrm{Sr}$ ratio $\left(>3600\right.$ ), equivalent to ${ }^{87} \mathrm{Rb} /{ }^{86} \mathrm{Sr}$ $=11,000$. The radiogenic $\mathrm{Sr}$ and low $\mathrm{Sr}$ contents make these samples extremely sensitive to any form of contamination. Despite the young age of the Glass Mountain lavas $(<2.1 \mathrm{Ma})$ the large range in $\mathrm{Rb} / \mathrm{Sr}$ ratios result in variable presentday ${ }^{87} \mathrm{Sr} /{ }^{86} \mathrm{Sr}(0.7173-1.0012)$. The $\mathrm{Sr}$ isotope ratios calculated for the time of eruption determined by $\mathrm{Ar}$ dating $\left({ }^{87} \mathrm{Sr} /{ }^{86} \mathrm{Sr}_{\mathrm{e}}\right)$ are also variable, ranging from 0.7059 to 0.7196 . There is no simple temporal relationship between the age of the lavas and ${ }^{87} \mathrm{Sr} /{ }^{86} \mathrm{Sr}_{\mathrm{e}}$ (Table 2 [4]).

\subsection{Mineral $R b-S r$ isotope data}

Mineral phases from different samples have large variations in present-day $\mathrm{Sr}$ isotope compositions (e.g., bulk sanidine $=0.7078-0.7179$ (Table 3)). Duplicate $\mathrm{Sr}$ isotope analyses of sanidine and plagioclase composites and individual grains free of overgrowths from sample OD are within analytical error, which implies that the feldspars represent single populations (Table 3 ). A precise ${ }^{87} \mathrm{Sr} /{ }^{86} \mathrm{Sr}$ profile across individual feldspar grains has, so far, proved impossible owing to the relatively low Sr concentrations. Core-rim relation-

Table 2

$\mathrm{Rb}-\mathrm{Sr}$ isotope data for older lavas from Glass Mountain

\begin{tabular}{|c|c|c|c|c|c|c|c|c|}
\hline \multicolumn{2}{|c|}{$\begin{array}{l}\text { SAMPLE } \\
\text { inner lavas }\end{array}$} & \multirow{2}{*}{$\begin{array}{r}\text { AGE } \mathrm{Ma}^{\mathrm{I}} \\
1.990^{2}\end{array}$} & \multirow{2}{*}{$\begin{array}{c}\text { Rb ppm } \\
\quad 311.6\end{array}$} & \multirow{2}{*}{$\begin{array}{l}\text { Sr ppm } \\
\\
\quad 0.149\end{array}$} & \multirow{2}{*}{$\begin{array}{c}\mathrm{Rb} / \mathrm{Sr} \\
2087\end{array}$} & \multirow{2}{*}{$\begin{array}{c}{ }^{87} \mathrm{Rb} /{ }^{86} \mathrm{Sr} \\
6143\end{array}$} & \multirow{2}{*}{$\begin{array}{c}{ }^{87} \mathrm{Sr}{ }^{86} \mathrm{Sr} \\
0.88389_{ \pm 1}\end{array}$} & \multirow{2}{*}{$\begin{array}{r}{ }^{87} \mathrm{Sr}^{86} \mathrm{Sr}_{\mathrm{e}}{ }^{3} \\
0.71032\end{array}$} \\
\hline $\mathrm{OC}$ & GLASS & & & & & & & \\
\hline ON & GLASS & 1.77 & 169.5 & 0.765 & 221.6 & 642.1 & $0.72484 \pm 1$ & 0.70870 \\
\hline OM & GLASS & 1.77 & 177.3 & 1.168 & 151.8 & 439.7 & $0.71883 \pm 1$ & 0.70778 \\
\hline OD & GLASS & $1.686^{2}$ & 288.4 & 2.260 & 127.6 & 369.5 & $0.71726 \pm 1$ & 0.70841 \\
\hline OF & GLASS & $?$ & 165.2 & 0.726 & 227.5 & 659.5 & $0.72509 \pm 1$ & \\
\hline $\mathrm{OZ}$ & GLASS & $?$ & 202.4 & 0.688 & 294.4 & 853.7 & $0.73079 \pm 1$ & \\
\hline \multicolumn{9}{|c|}{ outer lavas } \\
\hline OK & GLASS & 1.89 & 184.2 & 0.160 & 1153 & 3366 & $0.79619 \pm 1$ & 0.70585 \\
\hline $\mathrm{OL}$ & GLASS & $1.867^{2}$ & 249.9 & 0.0687 & 3637 & 10827 & $1.00215 \pm 3$ & 0.71526 \\
\hline $\mathrm{OB}$ & WR & 1.74 & 207.1 & 0.105 & 1972 & 5792 & $0.86136 \pm 1$ & 0.71824 \\
\hline OJ & GLASS & 1.6 & 187.3 & 0.164 & 1142 & 3333 & $0.79527 \pm 1$ & 0.71955 \\
\hline OI & GLASS & 1.44 & 191.2 & 0.473 & 404.2 & 1173 & $0.73761 \pm 1$ & 0.71363 \\
\hline
\end{tabular}

\footnotetext{
${ }^{1} \mathrm{~K}-\mathrm{Ar}$ ages from [7]; ${ }^{20} \mathrm{Ar}-{ }^{39} \mathrm{Ar}$ ages from sanidine (see Table 1 ) $;{ }^{3}$ initial ratios calculated at time of eruption defined by Ar ages.
} 


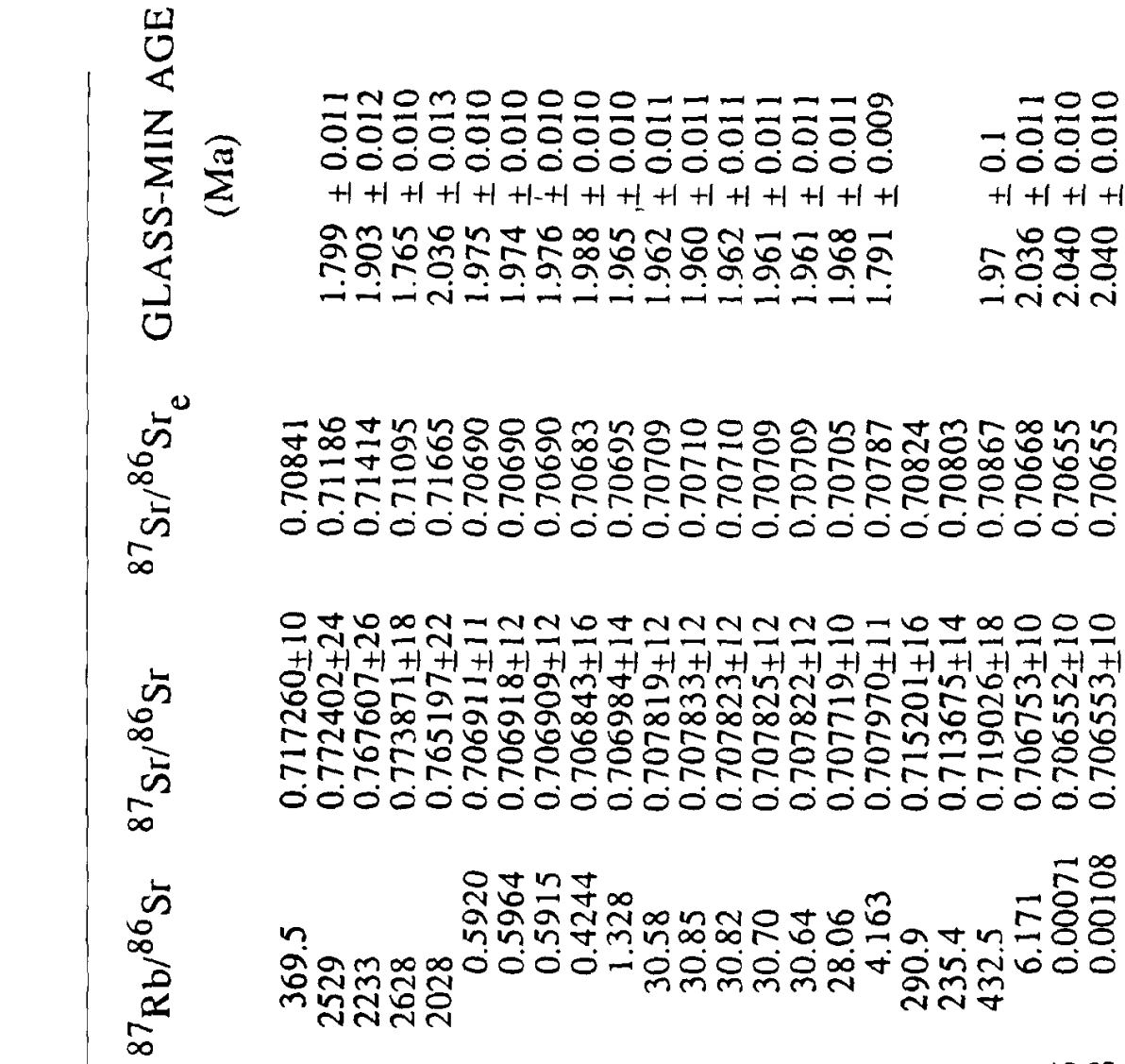

둉 ㅈํㅇํㅇ 000 $+1+1+$ mู तin

กีธ్రㄴㅁㅇ

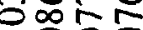
장ㅇㅇㅇ ๑0்0

$=\ln 2$ $+1+1+1$ ํํำ $\infty$ 我 象 舟足 ๑ं்

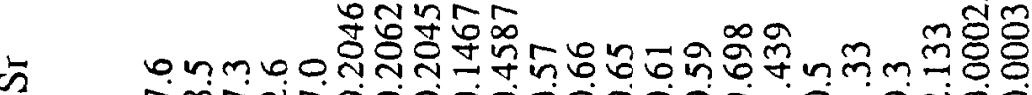

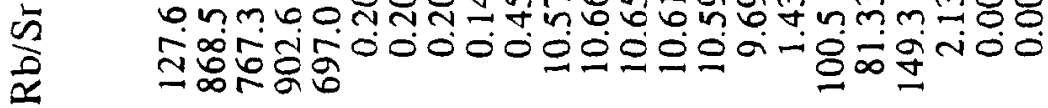

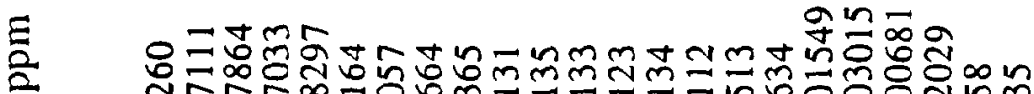
步

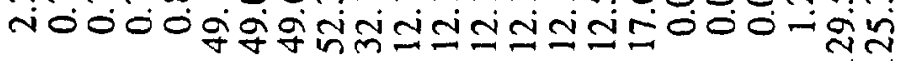

$r \infty m$ वन̄ 우음 ०ं०்

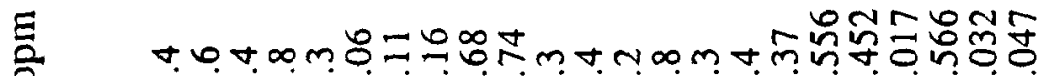

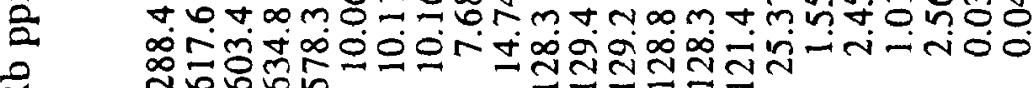
स्थ , 密迹 m过

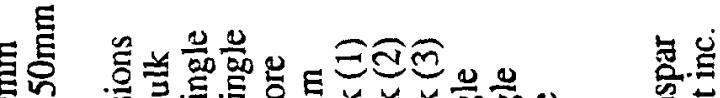

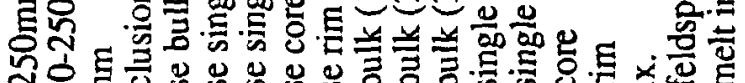

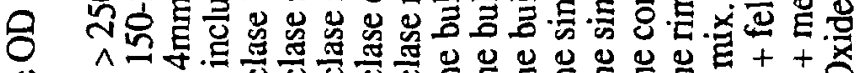

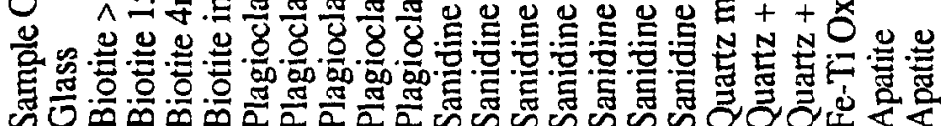

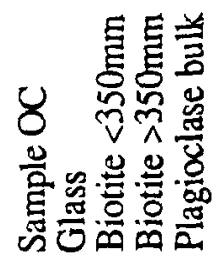




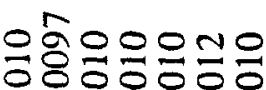

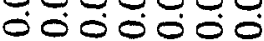
$+1+1+1+1+1+1+1$

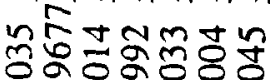
तininini

운ํํำำำ

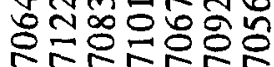
0000000

$\nabla N= \pm N N \pm$ $+1+1+1+1+1+1$

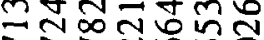
FNN Ning ถูก NRFNER 0000்00

$-\infty$

- 60,090 - imión

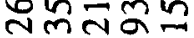

$\infty \overline{0}$ mingñ

nm₹n+สิ๊ ปกล์ मलि-

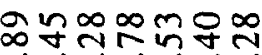

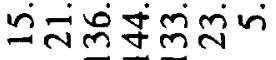

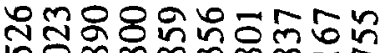
ผ $0 \infty \infty \infty m \infty \infty$

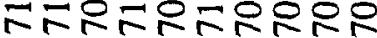
ம0்0்0்0்0்

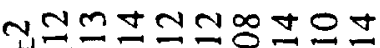
$+1+1+1+7+1+1+1+1$

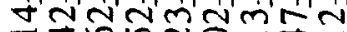

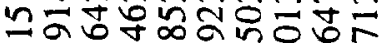

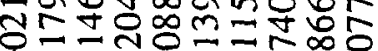

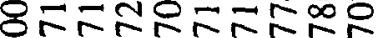
- 000000000

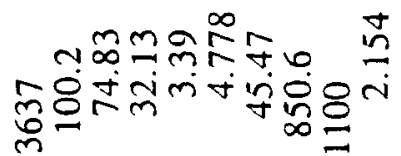

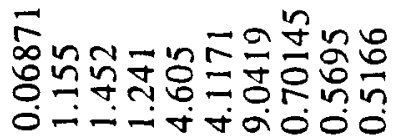

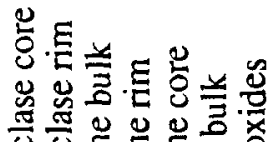

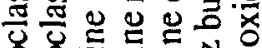

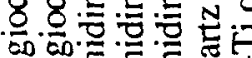

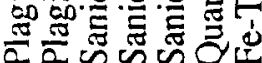

annจำ

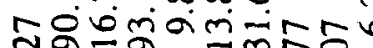

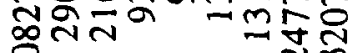
$\sim m$

\section{$+1$} क⿻ की .00000000 
ships were investigated, however: Both sanidine and plagioclase core samples have less measured radiogenic ${ }^{87} \mathrm{Sr} /{ }^{86} \mathrm{Sr}$ than the bulk separates and individual grains (e.g., 0.70772 compared to 0.70782 for sanidine in OD). Feldspar rims are more radiogenic than the cores and bulk separates $(0.70698$ compared to $0.70686-0.70691$ in OD plagioclase). Plagioclase overgrowths on sanidine are also significantly more radiogenic (OD sanidine $=0.70797$ compared to 0.70772) despite having a lower $\mathrm{Rb} / \mathrm{Sr}$ ratio comparable to that of the plagioclase separates. Large core-to-rim isotopic disequilibria are also found in sanidines from samples OL and OC (e.g., 0.715-0.720 and $0.7127-0.7202$ ). All the quartz separates have low absolute $\mathrm{Rb}$ and $\mathrm{Sr}$ contents. The feldspar-bearing quartz has relatively low $\mathrm{Rb} / \mathrm{Sr}$ compared to the host glass, whereas the quartz separate that contains melt inclusions has $\mathrm{Rb} / \mathrm{Sr}$ and ${ }^{87} \mathrm{Sr} /{ }^{86} \mathrm{Sr}$ ratios higher than the host glass.

\section{4. $\mathrm{Pb}$ and $\mathrm{Nd}$ isotope compositions}

$\mathrm{Pb}$ and $\mathrm{Nd}$ isotope data are presented in Table 4 for samples $\mathrm{OC}, \mathrm{OD}$ and $\mathrm{OL}$, complementing fourteen $\mathrm{Nd}$ and nine $\mathrm{Pb}$ isotope analyses reported previously [4]. A striking feature of these results is the good agreement between all the data. There are no $\mathrm{Nd}$ and $\mathrm{Pb}$ isotope disequilibria between different phases within a sample, providing unequivocal evidence against late crustal contamination (Table 4).

Table 4

Mineral $\mathrm{Nd}$ and $\mathrm{Pb}$ isotope ratios

\begin{tabular}{|c|c|c|c|c|}
\hline Sample & ${ }^{143} \mathrm{Nd} /{ }^{144} \mathrm{Nd}$ & ${ }^{206} \mathrm{~Pb} /{ }^{204} \mathrm{~Pb}$ & ${ }^{207} \mathrm{~Pb} /{ }^{204} \mathrm{~Pb}$ & ${ }^{208} \mathrm{~Pb} /{ }^{204} \mathrm{~Pb}$ \\
\hline $\begin{array}{l}\text { OD glass }{ }^{1} \\
\text { OD whole rock } \\
\text { OD sanidine } \\
\text { OD plagioclase } \\
\text { OD sanidine } \\
\text { OD biotite }>250 \mathrm{~mm} \\
\text { OD Fe-Ti oxides }\end{array}$ & $\begin{array}{l}0.512467 \pm 16 \\
0.512476 \pm 14 \\
0.512494 \pm 17 \\
0.512467 \pm 10 \\
0.512469 \pm 9 \\
0.512475_{ \pm} 8 \\
0.512471 \pm 8\end{array}$ & $\begin{array}{l}19.163 \\
19.146 \\
19.148 \\
19.145 \\
19.157 \\
19.144\end{array}$ & $\begin{array}{l}15.695 \\
15.679 \\
15.661 \\
15.670 \\
15.672 \\
15.665\end{array}$ & $\begin{array}{l}39.007 \\
38.927 \\
38.888 \\
38.905 \\
38.920 \\
38.913\end{array}$ \\
\hline $\begin{array}{l}\text { OC glass }{ }^{1} \\
\text { OC glass } \\
\text { OC whole rock }{ }^{1} \\
\text { OC sanidine } \\
\text { OC plagioclase } \\
\text { OC biotite }>350 \mathrm{~mm} \\
\text { OC Fe-Ti oxides }\end{array}$ & $\begin{array}{l}0.512438 \pm 13 \\
0.512449 \pm 8 \\
0.512455 \pm 17 \\
0.512454 \pm 10 \\
0.512446 \pm 9 \\
0.512452 \pm 8 \\
0.512447 \pm 9\end{array}$ & $\begin{array}{l}19.15 \% \\
19.150 \\
19.146 \\
19.153 \\
19.147 \\
19.159\end{array}$ & $\begin{array}{l}15.689 \\
15.672 \\
15.679 \\
15.680 \\
15.672 \\
15.675\end{array}$ & $\begin{array}{l}38.975 \\
38.925 \\
38.977 \\
38.932 \\
38.917 \\
38.925\end{array}$ \\
\hline $\begin{array}{l}\text { OL whole rock } \\
\text { OL sanidine }^{1} \\
\text { OL glass } \\
\text { OL plagioclase } \\
\text { OL sanidine } \\
\text { OL Fe-Ti oxides }\end{array}$ & $\begin{array}{l}0.512481 \pm 15 \\
0.512484 \pm 25 \\
0.512467 \pm 8 \\
0.512474 \pm 8 \\
0.512462 \pm 9 \\
0.512473_{ \pm} 8\end{array}$ & $\begin{array}{l}19.158 \\
19.147 \\
19.152\end{array}$ & $\begin{array}{l}15.675 \\
15.679 \\
15.665\end{array}$ & $\begin{array}{l}38.931 \\
38.924 \\
38.919\end{array}$ \\
\hline
\end{tabular}

The centre of a $1 \times 2 \mathrm{~cm}$ xenolith from $\mathrm{OL}$ has the following $\mathrm{Sr}-\mathrm{Nd}$ isotope composition: ${ }^{87} \mathrm{Sr} /{ }^{86} \mathrm{Sr}=0.710805 \pm 10,{ }^{143} \mathrm{Nd} /{ }^{144} \mathrm{Nd}$ $=0.512057 \pm 9$. Elemental concentrations $(\mathrm{ppm}): \mathrm{Rb}=45.3, \mathrm{Sr}=237.7\left({ }^{87} \mathrm{Rb} /{ }^{86} \mathrm{Sr}=0.55\right) ; \mathrm{Sm}=3.52, \mathrm{Nd}=17.57\left({ }^{147} \mathrm{Sm} /{ }^{144} \mathrm{Nd}\right.$ $=0.121)^{1}$ From Halliday et al. [4]. 


\section{5. $R b-S r$ isochron ages}

Lavas closest to the caldera margin (see Fig. 1) define a $\mathrm{Rb}-\mathrm{Sr}$ isochron of $2.049 \pm 0.013 \mathrm{Ma}$. Omitting whole-rock sample OD, which records petrographic evidence of minor hydration, reduces the MSWD from 21.8 to 11.1 with little effect on the isochron age $(2.047 \pm 0.013 \mathrm{Ma}$, Fig. $3 \mathrm{~A})$. These new data obtained on hand-picked glass are within error of the whole-rock $\mathrm{Rb}-\mathrm{Sr}$ isochron age determined previously [4] (2.09 \pm $0.06 \mathrm{Ma}$ ), confirming that the lavas have suffered little post-eruption alteration. Lavas more distant from the caldera wall define a $\mathrm{Rb}-\mathrm{Sr}$ isochron age of $1.894 \pm 0.013 \mathrm{Ma}$ with a MSWD of 2.3 (Fig. $3 \mathrm{~B}$ ), within error of that determined previously [4] $(1.90 \pm 0.02 \mathrm{Ma})$. Initial ratios for the two suites are indistinguishable $\left({ }^{87} \mathrm{Sr} /{ }^{86} \mathrm{Sr}=0.7063\right.$ \pm 2 and $0.7062 \pm 2$ ), which, coupled with comparable $\mathrm{Nd}$ and $\mathrm{Pb}$ isotope compositions, implies a similar origin. If the two rhyolite suites are derived from the same source the initial $\mathrm{Sr}$ ratios constrain the $\mathrm{Rb} / \mathrm{Sr}$ ratio of that source to be $<80 \pm 14$ even though lavas with $\mathrm{Rb} / \mathrm{Sr}>3000$ were produced. The dividing line between inner and outer lavas trends NW-SE and is subparallel to the regional trend of the Sierran frontal es-

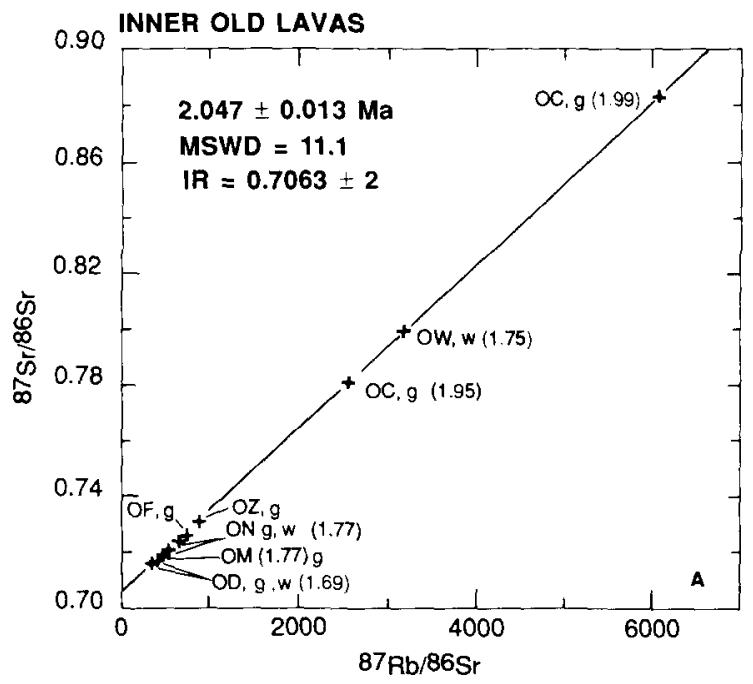

carpment fault and basement faults in the Long Valley region [16], possibly implying tectonic control in the formation of high-level magma reservoirs (Fig. 1).

\section{Discussion}

\subsection{Phenocryst-melt isotopic equilibration}

These data confirm the original observation made by Halliday et al. [4] that, despite being erupted over several hundred thousand years, the Glass Mountain rhyolites record $\mathrm{Rb}-\mathrm{Sr}$ isochron ages that are significantly older than the time of rhyolite eruption. The question now is whether these data can be used to distinguish between remelting of recently crystallised magmas $[10,11]$ and long magma residence times $[4,12]$. The fundamental difference between the two models is the length of time that the phenocryst populations have been in contact with a hot magma.

The origin of the minerals is fundamental to the interpretation of the $\mathrm{Rb}-\mathrm{Sr}$ isotope data; i.e., do they represent phenocrysts, xenocrysts or a combination of both? The $\mathrm{Nd}$ and $\mathrm{Pb}$ isotope ratios of the basement and local sediments are

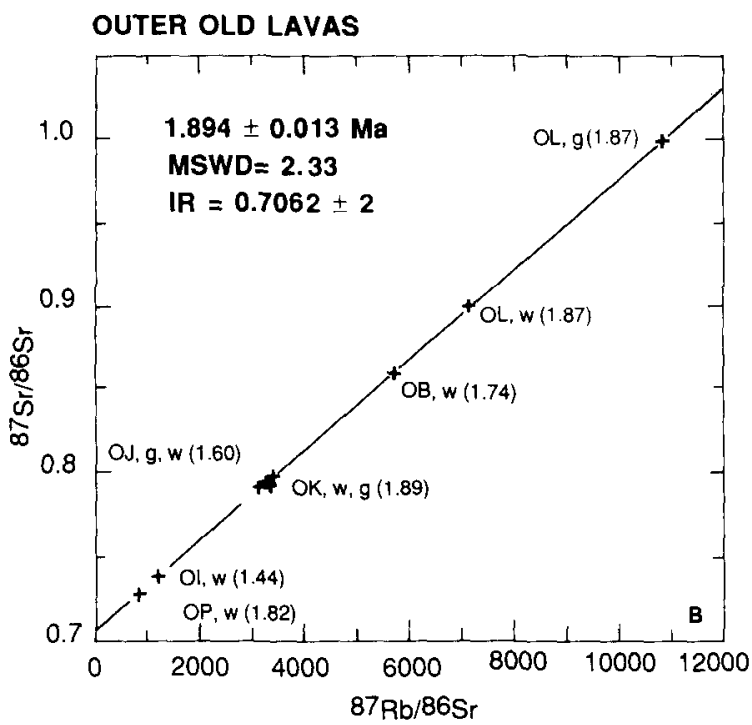

Fig. 3. $\mathrm{Rb}-\mathrm{Sr}$ isotope diagrams for (A) Inner Lavas and (B) Outer Lavas. Ages in parentheses are eruption ages determined from $\mathrm{K}-\mathrm{Ar}$ and $\mathrm{Ar}-\mathrm{Ar}$ ages ( $g=$ glass; $w=$ whole rock). 
heterogeneous, with many rocks having isotopic compositions distinct from those of the Glass Mountain rhyolites (e.g., ${ }^{206} \mathrm{~Pb} /{ }^{204} \mathrm{~Pb}=\mathrm{ca}$. $18.5-$ $20, \epsilon_{\mathrm{Nd}}=+6.5$ to $\left.-18,[17-23]\right)$. A small $(1 \times 2$ $\mathrm{cm})$ xenolith of basement material found in rhyolite OL confirms the isotopic difference of the basement (Table 4). Sampling of the mineral populations was biased by careful hand-picking such that any mineral thought to be from the very sparse xenocrystic population in OC and OL [8] has been removed. The success of the mineral picking has been confirmed by microprobe analyses of 50 representative grains from OD. Minerals from Glass Mountain lavas have $\mathrm{Nd}$ and $\mathrm{Pb}$ isotope ratios that are indistinguishable from their host glasses (Table 4), which again argues against the presence of a xenocryst population derived from the basement. Similarly, the single grain laser fusion ${ }^{40} \mathrm{Ar}-{ }^{39} \mathrm{Ar}$ ages are indistinguishable from corresponding bulk step-heating runs, implying that the sanidine samples represent a homogeneous population (Table 1). Therefore, with the possible exception of the excluded sparse xenocrysts, the phenocrysts in the Glass Mountain lavas are not derived from the basement. The $\mathrm{Nd}-\mathrm{Pb}-\mathrm{Ar}$ isotope data do not, however, preclude a xenocrystic contribution from older crystallised Glass Mountain magmas.

In the remelting and defrosting models $[10,11]$ minerals represent material that either crystallised following the remelting or survived the remelting event and then underwent a period of re-equilibration with the host. In the long magma residence model phenocrysts could be in contact with a melt for up to $360 \mathrm{ka}$. The Rb-Sr systematics of a phenocryst suspended in melt will reflect a combination of the growth of radiogenic ${ }^{87} \mathrm{Sr}$ since its formation and diffusive re-equilibration between the mineral and host melt during residence in a magma chamber. Strontium diffusion in sanidine may be an order of magnitude faster under hydrous conditions than anhydrous conditions [24-26]. Sr diffusion in anorthite is an order of magnitude slower than in sanidine and orthoclase [26]. Baker [27] has shown that across an interface between very different silicate melts tracer (or self-) diffusion for $\mathrm{Sr}$ is faster than volume diffusion by approximately one order of magnitude. However, where the major element concentration gradient is low (e.g., within an unzoned silicate mineral or melt) tracer and volume diffusion are comparable [28]. The $\mathrm{Sr}$ feldspar diffusion data discussed above [24-26] are therefore a good analogue for the equilibration of ${ }^{87} \mathrm{Sr} /{ }^{86} \mathrm{Sr}$. Fe-Ti oxide temperatures obtained from Glass Mountain obsidians are ca. $700^{\circ} \mathrm{C}$, similar to estimates for the early eruptive units of the Bishop Tuff $[8,29]$. At these temperatures, the estimated diffusion coefficient for sanidine is $\sim 10^{-17} \mathrm{~cm}^{2} / \mathrm{s}$ and $\sim 10^{-18} \mathrm{~cm}^{2} / \mathrm{s}$ for anorthite $[25,26]$.

Following Crank [30] and Christensen and Delaolo [5], the degree of 'effective equilibration' between a $0.5 \mathrm{~cm}$ radius sphere and an enclosing magma as a function of diffusivity has been calculated for different residence times. By 'effective equilibration' we mean the amount of $\mathrm{Sr}$ that has exchanged between the melt and the mineral. This can be expressed as the change in ${ }^{87} \mathrm{Sr} /{ }^{86} \mathrm{Sr}$ of the crystal (i.e., average ${ }^{87} \mathrm{Sr} /{ }^{86} \mathrm{Sr}$ of the crystal at time $t$ minus the initial ${ }^{87} \mathrm{Sr} /{ }^{86} \mathrm{Sr}$ of the crystal) divided by the difference between the initial ${ }^{87} \mathrm{Sr} /{ }^{86} \mathrm{Sr}$ ratios of the crystal and melt. For the estimated $\mathrm{Sr}$ diffusivity of the feldspars, it is apparent that the sanidine and plagioclase grains will undergo $<5 \%$ 'effective equilibration' over periods of up to $1 \mathrm{Ma}$. Total $\mathrm{Sr}$ isotope equilibration for plagioclase grains as small as $1 \mathrm{~mm}$ in radius would take more than $100 \mathrm{Ma}$. The greater the change in ${ }^{87} \mathrm{Sr} /{ }^{86} \mathrm{Sr}$ by radiogenic growth per unit time, the greater the $\mathrm{Sr}$ isotope disequilibrium between a crystal and a host magma. A 0.5 $\mathrm{cm}$ radius sphere that undergoes $5 \%$ 'effective equilibration' in $1.0 \mathrm{Ma}$ will undergo only $3 \%$ 'effective equilibration' in a magma with a ${ }^{87} \mathrm{Rb} /$ ${ }^{86} \mathrm{Sr}$ of 10,000 over the same period of time. The rhyolites have minimum melt compositions and should have formed at relatively low temperatures $\left(<750^{\circ} \mathrm{C}\right)[8]$. Any feldspars that grew at time $t_{0}$ and survived a remelting event at $t_{1}$ would only undergo limited $\mathrm{Sr}$ re-equilibration with their host magmas if the time between remelting (at $t_{1}$ ) and eruption (at $t_{2}$ ) were short. Rapid re-equilibration at higher temperatures can be ruled out because this would melt the entire source rock. If the Glass Mountain rhyolites 
formed by such remelting, all parts of unequilibrated individual feldspar grains, except any late rims that grew between $t_{1}$ and $t_{2}$, should lie on a mixing line between the core and the liquid on a $\mathrm{Rb}-\mathrm{Sr}$ isochron diagram. Late rims would plot off this line and initially record the $\mathrm{Sr}$ isotopic composition of the liquid at the time of precipitation. Protracted feldspar growth and partial re-equilibration in a long-lived magma reservoir would result in the main portions of the feldspars yielding mixed data that plot neither toward the glass nor the late overgrowth. The $\mathrm{Sr}$ isotope data for sanidine and plagioclase separates from samples $\mathrm{OC}, \mathrm{OD}$ and $\mathrm{OL}$ are presented in Table 3 and data for OD are presented graphically in Fig. 4. All feldspar composites and individual grain samples excluded material that contained thin translucent rims composed of plagioclase. However, the overgrowth was sampled during the microdrilling ('rim' in the diagrams). The feldspar populations plot above the regional isochrons (initial ratio of $0.7063 \pm 2$ ) and form slopes that are steeper than the isochrons. Plagioclases from OD define a slope equivalent to $\sim 31 \pm 5 \mathrm{Ma}$ whereas the sanidines define a slope of $\sim 3 \pm 1$ Ma (Fig. 4). The rims of plagioclase and sanidine do not lie on these regression lines. The Sr isotope systematics are consistent with the rims having formed in a later crystallisation event, at a time close to the eruption age. However, the bulk of the feldspars either formed over a long period of time or suffered significant isotopic exchange with the host magma prior to formation of the rims. Either way, this feature is most easily ex-
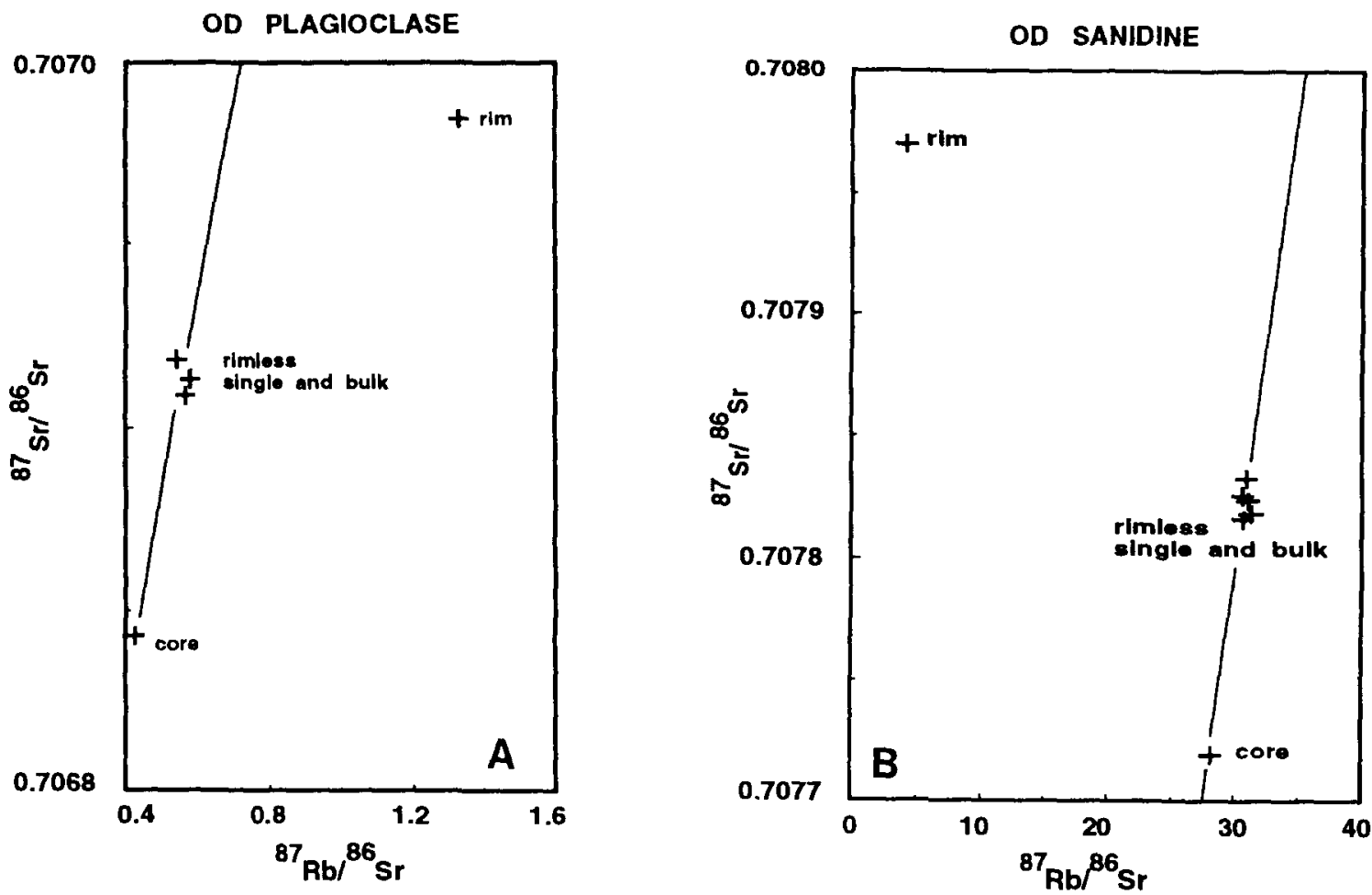

Fig. 4. Rb-Sr isotope diagram depicting feldspar data from sample OD. (A) Plagioclase. (B) Sanidine. All data lie above the regional isochron, which has an initial ratio of $0.7063 \pm 2$ such that the isochron lies well below the field defined by these diagrams. The regression lines on both figures are defined by grains without overgrowths and have a slope steeper than that of the regional isochron. These samples have $\mathrm{Sr}$ isotope systematics distinct from the overgrowths. 


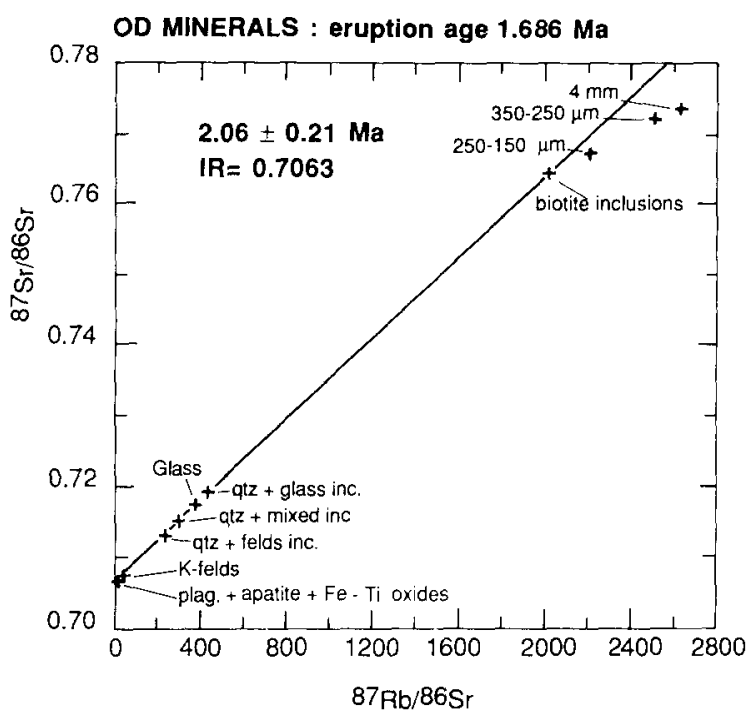

Fig. 5. Rb-Sr isotope diagram for the minerals from lava $\mathrm{OD}$.

plained if the grains resided in a magma for a significant period of time and cannot be so readily explained by the remelting models $[10,11]$.

\subsection{Crystallisation ages of the minerals}

The glass and bulk mineral separates of OD, excluding the biotite fractions, define a slope on a $\mathrm{Rb}-\mathrm{Sr}$ isochron diagram equivalent to an age of $2.06 \pm 0.21 \mathrm{Ma}$ (Fig. 5). Conventionally, these data would be interpreted as the cooling age of the rock following eruption. However, the sanidine and biotite ${ }^{40} \mathrm{Ar}-{ }^{39} \mathrm{Ar}$ ages $(1.686 \pm 0.011$ and $1.688 \pm 0.038 \mathrm{Ma})$ are significantly younger, precluding such an interpretation. Sample OD lies on the $2.047 \mathrm{Ma}$ regional glass isochron of the Inner Lavas and the mineral 'isochron' is within error of this age.

The Rb-Sr glass isochrons of the Glass Mountain Older Lavas record the timing of a marked fractionation in $\mathrm{Rb} / \mathrm{Sr}$. The low $\mathrm{Sr}$ contents and high $\mathrm{Rb} / \mathrm{Sr}$ ratios of the rhyolites cannot be generated by crustal melting and require the extensive fractionation of a mineral with a high $\mathrm{Sr}$ $K_{\mathrm{d}}$ such as feldspar [12,31]. Even if a subsequent remelting model is accepted the $\mathrm{Rb}-\mathrm{Sr}$ isochrons represent an earlier major chemical differentiation event during the evolution of the rhyolites when $\mathrm{Rb} / \mathrm{Sr}$ ratios were fractionated. The precision of the regional $\mathrm{Rb}-\mathrm{Sr}$ isochrons implies that this was completed in less than $26 \mathrm{ka}$ (Fig. 3).

The diffusion modelling establishes that the cores of large sanidine and plagioclase phenocrysts will retain $>99.9 \%$ of the $\mathrm{Sr}$ initially present at the time of crystallisation, even after 1.0 Ma of residence in a magma. Consequently, if the $\mathrm{Rb} / \mathrm{Sr}$ ratios of the melts do not significantly change during residence in the chamber, glassfeldspar core ages should define the time of crystal growth. The viscosity of the rhyolites and their low phenocryst population, coupled with preservation of the regional isochrons, enables us to
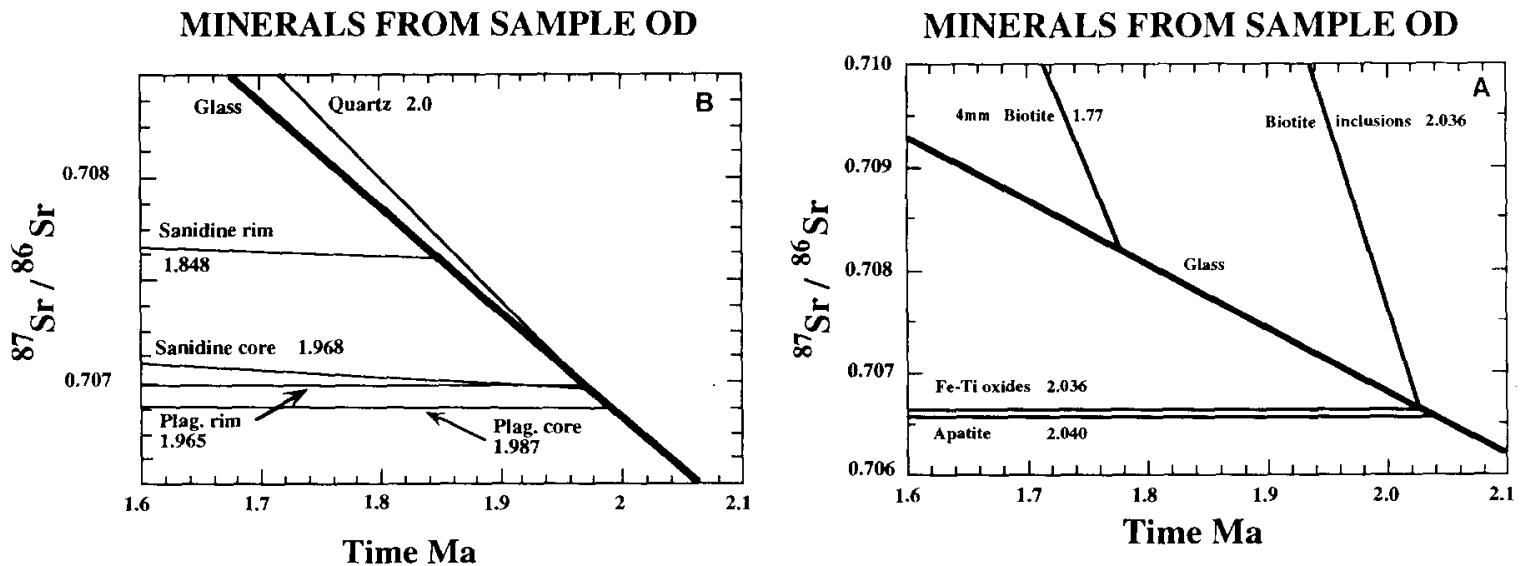

Fig. 6. Sr isotope evolution diagram for minerals from Glass Mountain lavas. (A) Early crystallised phases from sample OD. The eruption age of $\mathrm{OD}$ is $1.686 \pm 0.011 \mathrm{Ma}$. (B) Later crystallised phases from sample OD. 
OBSIDIAN OL
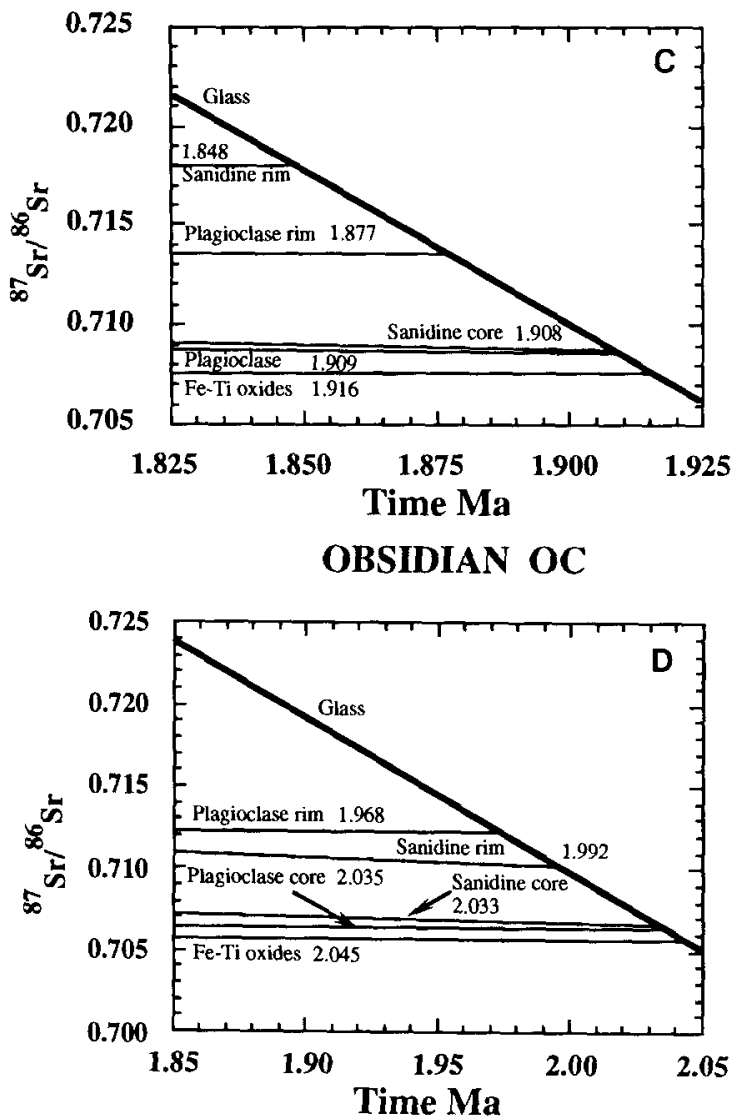

Fig. 6. (C) Minerals from sample OL with eruption age of $1.990 \pm 0.012 \mathrm{Ma}$. (D) Minerals from sample OC with eruption age of $1.867 \pm 0.005 \mathrm{Ma}$.

argue that the $\mathrm{Rb} / \mathrm{Sr}$ ratios of the magmas cannot have been further modified by extensive crystallisation.

Glass-mineral ages (hereafter referred to as mineral ages) are presented in Table 3 and graphically in Fig. 6. A partial derivative analysis of the error in the age difference between two phases (e.g., $t_{\text {plagioclase }}-t_{\text {sanidine }}$ ) demonstrates that the contribution from the analytical error of the glass is minor. The error in the age difference between minerals from a single sample is dominated by the analyses of the mineral phases. Errors in the age differences between two phases are below 1 ka for samples OC and OL, which have the highest glass $\mathrm{Rb} / \mathrm{Sr}$ (Table 5). Feldspar core ages from samples OC and OL are within error of the regional isochrons whereas the feldspar core ages from sample OD are younger but only just outside analytical uncertainty (Fig. 3 and Table 3 ).

Apatite, Fe-Ti oxide and biotite, which occur as inclusions in quartz and feldspar, crystallised before the bulk of the feldspar population. Fe-Ti oxide ages for all three samples are within error of the regional isochrons. Ages from the biotite inclusions from sample $O D$ are older than the feldspar cores and again within error of the regional isochron (Figs. 6A and $\mathrm{B}$ ). These older ages imply that the feldspars and quartz have effectively armoured the biotite and prevented equilibration with the magma. The apatite composites extracted from the biotite of sample OD record the oldest ages from this sample (Fig. 6A). Experimental studies of $\mathrm{Sr}$ diffusion in apatite have established that $\mathrm{Sr}$ diffusion is slow, of the order of $10^{-18} \mathrm{~cm}^{2} / \mathrm{s}[32-34]$. The calculated closure temperature for $\mathrm{Sr}$ in a $1 \mathrm{~mm}$ apatite grain is $\sim 700^{\circ} \mathrm{C}$ assuming a cooling rate between 10 and $1000^{\circ} \mathrm{C} / \mathrm{Ma}$, which is probably applicable for the Long Valley magma chamber(s) [32-34]. The apatite inclusions obtained from OD biotite phenocrysts retain the oldest mineral age, implying that the blocking temperature for apatite is as high as previously inferred [32-34] or that the biotite host has effectively armoured the apatite inclusions.

There is a perfect correspondence between the mineral ages and the order of crystallisation deduced from inclusion relationships (Fig. 6). These data are fully consistent with gradual crystallisation from a magma. There is no rationale in a remelting model that predicts these relationships. The sanidine and plagioclase cores from sample OD yield ages that are ca. 50 ka younger than the mineral thought to crystallise first. Plagioclase is older than sanidine, consistent with the inclusion relationships. Samples OC and OL have the same relative age relationships: the age of the bulk plagioclase separates are older than sanidine (Figs. 6C and D). Quartz consistently yields the youngest age but, due to the similar $\mathrm{Rb} / \mathrm{Sr}$ ratios between quartz and host glass, the error in the age is relatively large. While these data cannot be explained by the defrosting model [11] the miner- 
Table 5

Compilation of mineral ages

MINERAL PAIR

AGE

AGE DIFFERENCI

$\mathrm{Ma}$

Kyrs

LAVA OD $\mathrm{T}_{\text {regional }}=2.047 \pm 0.013 \mathrm{Ma} ; \mathrm{T}_{\text {erupt }}=1.686 \pm 0.011 \mathrm{Ma}$

Apatite

Fe-Ti oxides

2.0404

2.0363

$4 \pm 3$

Fe-Ti oxides

2.0363

Biotite inclusions

2.0356

$0.7 \pm 18$

Biotite inclusions

2.0356

Plagioclase core

1.9875

$48 \pm 18$

Plagioclase core

1.9875

Sanidine core

1.9676

$20 \pm 4$

Plagioclase core

Plagioclase rim

1.9875

1.9654

$22 \pm 4$

Sanidine core

Sanidine rim

1.9676

1.7906

$177 \pm 4$

LAVA OC $T_{\text {regional }}=2.047 \pm 0.013 \mathrm{Ma} ; \mathrm{T}_{\text {erupt }}=1.990_{ \pm} 0.011 \mathrm{Ma}$

Fe-Ti oxides

Plagioclase core

Plagioclase core

Sanidine core

Plagioclase core

Plagioclase rim

Sanidine core

Sanidine rim

Fe-Ti oxides

Plagioclase

Plagioclase

Sanidine core

Plagioclase

Plagioclase rim

Sanidine core

Sanidine rim
2.0453

2.0350

$9.7 \pm 0.5$

2.0350

2.0328

$2.7 \pm 0.5$

2.0350

1.9677

$67.3 \pm 0.4$

2.0328

1.9922

$40.6 \pm 0.7$

LAVA OL $\mathrm{T}_{\text {regional }}=1.894_{ \pm} 0.013 \mathrm{Ma} ; \mathrm{T}_{\text {erupt }}=1.866_{ \pm} 0.014 \mathrm{Ma}$

1.9161

1.9093

$6.8 \pm 0.1$

1.9093

1.9081

$1.2 \pm 0.3$

1.9093

1.8770

$32.3 \pm 0.2$

1.9081

1.8480

$60.1 \pm 0.6$ 
als could have had a long magma residence time prior to solidification and subsequent remelting, provided the $\mathrm{Rb}-\mathrm{Sr}$ isotope systematics of the minerals were not disrupted by the remelting. In this case these data can still be used to infer the early crystallisation history of the magmas.

The time from apatite crystallisation to the initiation of sanidine crystallisation is $72 \pm 3 \mathrm{ka}$ for sample OD (Fig. 6A and B). The earliest dated phase to crystallise in $\mathrm{OL}$ and $\mathrm{OC}$ is $\mathrm{Fe}-\mathrm{Ti}$ oxide. The time between Fe- $\mathrm{Ti}$ oxide crystallisation and initiation of sanidine crystallisation is $12.4 \pm 0.6 \mathrm{ka}$ for $\mathrm{OC}$ and $8.0 \pm 0.3 \mathrm{ka}$ for $\mathrm{OL}$ (Figs. 6C and D). The age differences between plagioclase and sanidine cores show the same relative chronology: for OD $19.8 \pm 3.8 \mathrm{ka}$, for OC $2.8 \pm 0.5 \mathrm{ka}$, and for OL $1.2 \pm 0.3 \mathrm{ka}$. Lava OD is the most crystal rich and least evolved, displays the longest time difference between differentiation and eruption, and displays the slowest crystallisation rates. These relationships imply that the chemically more evolved samples (i.e., those with greater $\mathrm{Rb} / \mathrm{Sr}$ ratios) had shorter crystallisation histories, cooled more rapidly and were more liable to extrusion, possibly implying that they resided at shallower levels in a magma chamber. Note that these relationships are not readily predicted by the remelting models.

The maximum magma chamber residence for minerals from sample OD is $361 \mathrm{ka}$ (regional isochron age minus eruption age from 2.047 to $1.686 \mathrm{Ma})$. In this time period the ${ }^{87} \mathrm{Sr} /{ }^{86} \mathrm{Sr}$ of the magma would increase by 0.00189 . The differences in ${ }^{87} \mathrm{Sr} /{ }^{86} \mathrm{Sr}$ ratios at $1.686 \mathrm{Ma}\left({ }^{87} \mathrm{Sr} /{ }^{86} \mathrm{Sr}_{\mathrm{e}}\right)$ between core and bulk compositions for both sanidine and plagioclase are outside analytical uncertainty ( $0.00007 \pm 4$, Table 3$)$. In 360 ka a 5 $\mathrm{mm}$ radius feldspar grain would undergo a maximum of $1 \%$ equilibration with the host magma (i.e., a change in ${ }^{87} \mathrm{Sr} /{ }^{86} \mathrm{Sr}$ ratios of 0.00002 , close to the observed variation of $0.00007 \pm 4$ ). In contrast, the data from sample OL, which has the highest $\mathrm{Rb} / \mathrm{Sr}$ ratio and hence most rapid change in ${ }^{87} \mathrm{Sr} /{ }^{86} \mathrm{Sr}$, are incompatible with significant

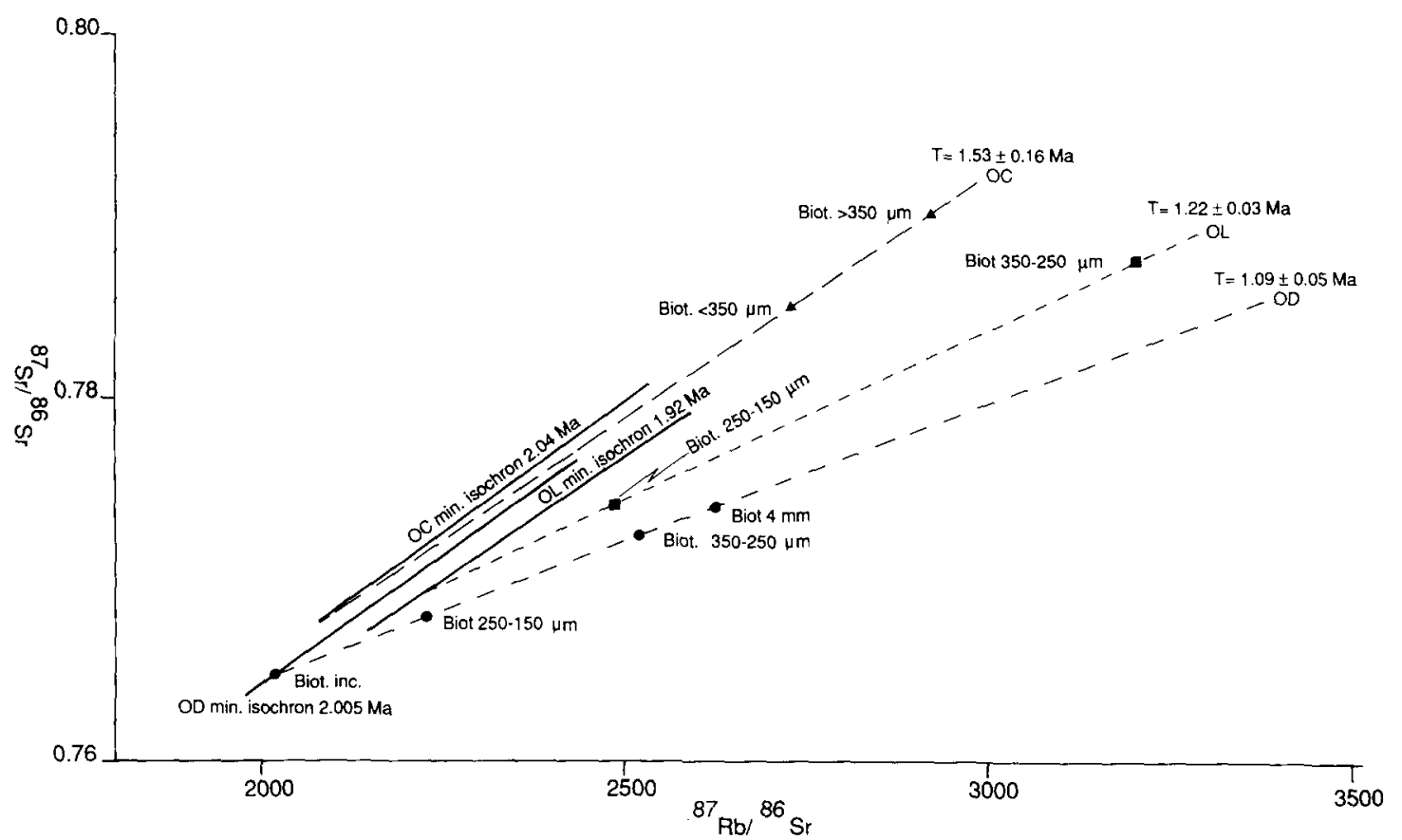

Fig. 7. Rb-Sr isotope diagram depicting the position of different biotite size fractions in relation to the mineral isochrons defined by plagioclase, sanidine, Fe-Ti oxide, quartz and glass for samples OD, OC and OL. In all cases biotite populations plot below the mineral isochrons even though the ${ }^{87} \mathrm{Sr} /{ }^{86} \mathrm{Sr}$ ratio of the host glasses varies from significantly less radiogenic than the biotites (OD) to more radiogenic (OC and $\mathrm{OL}$ ). See text for further discussion. 
re-equilibration. The difference in ${ }^{87} \mathrm{Sr} /{ }^{86} \mathrm{Sr}_{\mathrm{e}}$ ratios between core and bulk sanidine compositions is 0.0033 . The maximum time difference between eruption of $\mathrm{OL}(1.866 \pm 0.14 \mathrm{Ma})$ and the regional isochron $(1.893+0.013)$ is $54 \mathrm{ka}$. In this time the ${ }^{87} \mathrm{Sr} /{ }^{86} \mathrm{Sr}$ of the magma would increase by 0.0083 . However, in such a short time little $\mathrm{Sr}$ isotope re-equilibration would occur between the magma and minerals $(<0.1 \%)$, suggesting that the bulk and single grain mineral data are recording variations in the time of mineral formation.

The translucent rims of both plagioclase and sanidine from $\mathrm{OL}$ and $\mathrm{OC}$ yield $\mathrm{Rb}-\mathrm{Sr}$ ages within error of their respective eruption ages. The rims were sampled by microdrill and probably represent a mixture of the thin $(0.1 \mathrm{~mm})$ overgrowth and a minor portion (probably close to $15 \%$ ) of the interior. The estimated residence times for the feldspar of samples OL and OC are 60.1 and $67.3 \mathrm{ka}$ respectively (core ages minus eruption age, Table 5). Diffusion calculations show that the outer $0.2 \mathrm{~mm}$ of a $5 \mathrm{~mm}$ radius grain would undergo ca. 20\% Sr equilibration in $100 \mathrm{ka}$ assuming a diffusivity of $\mathrm{Sr}$ of $10^{-17} \mathrm{~cm}^{2} / \mathrm{s}$ and a moderate increase in radiogenic ${ }^{87} \mathrm{Sr}\left({ }^{87} \mathrm{Rb} /{ }^{86} \mathrm{Sr}\right.$ $=1000$ ). The short residence times of feldspar in samples OL and OC demonstrate that the rim ages cannot be interpreted entirely in terms of equilibration. This conclusion is confirmed by the sanidine rim from sample OD which gives an age that is $177 \mathrm{ka}$ younger than the core and $105 \mathrm{ka}$ older than the age of eruption. If considered simply in terms of re-equilibration, these age relationships would imply ca. $60 \%$ equilibration between the mineral and magma, far too large to ascribe simply to diffusive processes. Given the rapid change in ${ }^{87} \mathrm{Sr} /{ }^{86} \mathrm{Sr}$ with time and the short residence times for samples $O C$ and $O L$ it can be concluded that the feldspar rims in these samples grew at a time indistinguishable from that corresponding to the eruption age. Hence, it can be also concluded that plagioclase and sanidine growth occurred over periods of $30-60 \mathrm{ka}$ in sample OL and 67-40 ka in sample OC. Due to the effects of re-equilibration, the $177 \mathrm{ka}$ difference between sanidine core and rim ages of sample OD is probably an over-estimate by between 5 and $15 \%$, depending on the true residence time. The $t_{\text {core }}-t_{\text {rim }}$ for plagioclase from OD is only $22 \mathrm{ka}$, which represents $7 \%$ of the plagioclase residence time. This is indistinguishable from the calculated degree of equilibration in 300 ka. Within an individual sample, ages obtained from cores, composite separates and individual grains from both sanidine and plagioclase are similar (Table 4). Therefore the bulk of the feldspar crystallisation was probably rapid $(<15$ ka).

\subsection{Biotite Rb-Sr isotope systematics}

Currently there are on;y limited $\mathrm{Sr}$ diffusion data for biotite [35,36]. $\mathrm{K}$ and $\mathrm{Rb}$ data [35] suggest diffusivities of ca. $10^{-13} \mathrm{~cm}^{2} / \mathrm{s}$ at the magmatic temperatures of the Glass Mountain rhyolites. Providing that $\mathrm{Sr}$ and $\mathrm{Rb}$ diffusion in biotite are not more than several orders of magnitude different and even accounting for the rapid changes in the ${ }^{87} \mathrm{Sr} /{ }^{86} \mathrm{Sr}$ ratio of the melt, a $1 \mathrm{~cm}$ long biotite xenocryst would undergo almost total equilibration with a magma in $<25 \mathrm{ka}$. The different size biotite populations from OD yield mineral ages $(1.90-1.77 \pm 0.01 \mathrm{Ma})$ that are younger than the regional glass isochron age of $2.047 \pm 0.013 \mathrm{Ma}$, but older than the eruption age $1.676 \pm 0.011 \mathrm{Ma}$. In contrast, the biotite inclusion composite separated from quartz and feldspar yields an age of $2.036 \pm 0.013 \mathrm{Ma}$, indistinguishable from the regional isochron but $48 \mathrm{ka}$ older than the plagioclase core. Biotite composites from samples $\mathrm{OC}$ and $\mathrm{OL}$ were also in $\mathrm{Sr}$ isotope disequilibrium with their host at the time of eruption (Fig. 7). Biotite fractions from all three samples have high $\mathrm{Rb} / \mathrm{Sr}$ ratios (ca. 1000) and plot below the regional glass isochrons on the $\mathrm{Rb}-\mathrm{Sr}$ isochron diagram, demonstrating that these populations contain little, if any, xenocrystic material from the country rocks. Biotite-glass ages for samples $O C$ and $O L$ are older than the regional isochrons due to the biotites having lower $\mathrm{Rb} / \mathrm{Sr}$ ratios than the glass and plotting below the isochrons. The coarsest biotite size fraction of sample OD gives the youngest apparent age $(1.765 \pm 0.010 \mathrm{Ma})$. Diffusion-controlled processes would produce the opposite relationship, with smaller grains undergoing the greatest iso- 
topic exchange. The different biotite size fractions of OD define a mixing relationship on a $\mathrm{Rb}-\mathrm{Sr}$ isochron diagram (Fig. 7). Biotites from samples $\mathrm{OL}$ and $\mathrm{OC}$ are also discordant from their respective mineral isochrons, with the coarser grain size fractions the most discordant. The relationships defined by all three biotite populations can be interpreted in terms of mixing between biotite inclusions armoured by quartz or feldspar and larger phenocrysts that have undergone isotopic exchange with the magma and/or grown later. Smaller biotite size fractions are interpreted to contain a greater proportion of biotite inclusions liberated from host quartz and feldspar grains during sample crushing. A mineral with lower $\mathrm{Rb} / \mathrm{Sr}$ and ${ }^{87} \mathrm{Sr} /{ }^{86} \mathrm{Sr}$ ratios than the host magma which undergoes $\mathrm{Sr}$ isotope exchange with the magma results in a mineral with increased ${ }^{87} \mathrm{Sr} /{ }^{86} \mathrm{Sr}$ ratios that plots above the mineral isochron. Despite having lower ${ }^{87} \mathrm{Sr} /{ }^{86} \mathrm{Sr}$ and $\mathrm{Rb} / \mathrm{Sr}$ than their host lava, the biotites of samples OL and OC do not show this relationship. Similarly, the larger biotite size fractions of $\mathrm{OD}$ have increased $\mathrm{Rb} / \mathrm{Sr}$ and ${ }^{87} \mathrm{Sr} /{ }^{86} \mathrm{Sr}$ ratios compared to the biotite inclusion population, causing them to plot below the mineral isochrons. These data can be explained if the $\mathrm{Rb} / \mathrm{Sr}$ ratio of the biotite increases after crystallisation by partial re-equilibration with the melt. For this model to be valid the $\mathrm{Rb} / \mathrm{Sr}$ ratio of the liquid or the equilibrium partition coefficient must change after crystallisation of the biotite. A more likely explanation is that the larger biotites represent xenocrysts from earlier crystallised Glass Mountain rhyolites elsewhere in the magma chamber. This would help explain the similar $\mathrm{Rb} / \mathrm{Sr}$ ratios of the biotites irrespective of the host glass $\mathrm{Rb} / \mathrm{Sr}$ ratio and the small amounts of excess $\mathrm{Ar}$ found in the biotites from OD. However, mixing of material between different levels of the magma chamber must have been limited in order to preserve the regional $\mathrm{Rb}-\mathrm{Sr}$ isochron.

\subsection{Mineral growth rates}

Current estimates of magma crystallisation rates come principally from studies of rapidly cooling 'basaltic systems' [6]. Minimum mineral growth rates for the Glass Mountain rhyolites can be calculated by assuming that grains grew over the entire period of residence in the magma chamber. The growth rates calculated below are average linear growth rates and are not intended to obscure a more complex history of mineral growth that almost certainly occurred. The largest feldspar grains are up to $1 \mathrm{~cm}$ in diameter (i.e., $0.5 \mathrm{~cm}^{3}$ ). Assuming a maximum residence time of $360 \mathrm{ka}$ for sample OD and $32 \mathrm{ka}$ for OL yields growth rates of between $1.4 \times 10^{-6}$ and $8.7 \times$ $10^{-5} \mathrm{~cm}^{3} / \mathrm{yr}$. The mineral $\mathrm{Sr}$ isotope systematics indicate, however, that growth rates were faster. The plagioclase in sample OD grew in significantly less time than $22 \mathrm{ka}$ (the maximum age difference between core and rim assuming no effects from diffusion), which implies an average growth rate of $2.4 \times 10^{-5} \mathrm{~cm}^{3} / \mathrm{yr}$. This equates to a linear growth rate of $7.2 \times 10^{-13} \mathrm{~cm} / \mathrm{s}$. The extent to which mineral growth was continuous or episodic is unknown, but large differences between the feldspar rim ages and the eruption age of sample OD implies that crystallisation stopped long before eruption. Coupled with the fact that feldspar cores and bulk grains yield similar ages and the presence of the thin plagioclase overgrowths on sanidine grains, these observations are indicative of episodic growth, which imply that faster growth rates operated at least periodically, but we are unable to constrain maximum growth rates.

Growth rates can also be determined from inclusion relationships. Plagioclase crystals are found forming the nucleus of sanidine grains in all three samples. The time difference between the formation of plagioclase and sanidine cores is $19.8 \pm 3.8 \mathrm{ka}$ for sample OD and $2.7 \pm 0.5 \mathrm{ka}$ for sample OC. The size of the plagioclase inclusions was determined from the largest sanidine grains, which are assumed to have been the first sanidines to begin crystallising. The largest plagioclase inclusions are $0.1 \mathrm{~cm}$ long, and they must have grown before the onset of sanidine growth. This implies a linear growth rate of $5.9 \pm 1.1 \times$ $10^{-13} \mathrm{~cm} / \mathrm{s}$ for sample $\mathrm{OC}$ and $8.0 \pm 1.3 \times 10^{-14}$ $\mathrm{cm} / \mathrm{s}$ for OD, similar to estimates for the Bishop Toff [5]. The faster growth rate would produce a feldspar $11 \mathrm{~cm}$ in diameter in the $300 \mathrm{ka}$ resi- 
dence time of plagioclase in sample $O D$, demonstrating that feldspar crystallisation was not continuous in the magma system over the entire magmatic history of the lavas.

\subsection{Magma production rates}

The $\mathrm{Rb} / \mathrm{Sr}$ ratios of up to 3600 at Glass Mountain require that a parental magma with $100 \mathrm{ppm} \mathrm{Sr}$ (typical value for crustal melts) undergoes $>99 \%$ fractionation of an assemblage with a bulk $\mathrm{Sr} K_{\mathrm{d}}$ of $>2$ (i.e., dominated by sanidine and plagioclase [31]). It is impossible that the observed sparse phenocryst population at Glass Mountain was responsible for magma differentiation. The volume of the entire magma system is unknown due to disruption by caldera formation. The total amount of pre-1.2 Ma lavas present today is $>20 \mathrm{~km}^{3}$, which places a lower limit on the size of the magma chambers [8]. The fact that the Older Lavas lie on regional isochrons with precisions of $\pm 13,000 \mathrm{yr}$ implies that the precursor to the silicic magma differentiated rapidly and produced high-silica rhyolite at a rate of at least $0.8 \times 10^{-3} \mathrm{~km}^{3} / \mathrm{yr}$.

Eruption of Glass Mountain lavas terminated with eruption of the Bishop Tuff and the formation of the Long Valley Caldera. Isotopic similarities between post-1.2 Ma lavas and the Bishop Tuff [9] imply derivation from the same magma and hence that $>700 \mathrm{~km}^{3}$ of magma was produced between ca. 1.1 and $0.74 \mathrm{Ma}$. This would imply a production rate of $1.9 \times 10^{-3} \mathrm{~km}^{3} / \mathrm{yr}$, comparable to the estimate made by Christensen and DePaolo [5]. However, the post-1.2 Ma lavas also define regional isochrons (e.g., $1.151 \pm 0.010$ Ma [37]), demonstrating a rapid differentiation process. If the Bishop Tuff magma were produced in these events a production rate of $3.5 \times$ $10^{-2} \mathrm{~km}^{3} / \mathrm{yr}$ is implied.

Previous estimates of the production rate of silicic magma systems have been based on the relationships between eruptive volume and repose time [1]. Recent compilations conclude production rates are of the order of $10^{-2}-10^{-4}$ $\mathrm{km}^{3} / \mathrm{yr}$, with a mean of $10^{-3} \mathrm{~km}^{3} / \mathrm{yr}$ [2]. The data presented here argue for magma production as an episodic rather than continuous process. Hence, the production rates of silicic systems determined in previous studies $[1,2]$ may be too low and in reality are probably more comparable to basaltic systems than previously realised (e.g., $\left.10^{-2} \mathrm{~km}^{3} / \mathrm{yr}[38]\right)$.

\section{Acknowledgements}

This work was supported by National Science Foundation grants EAR 8915986, 9004133 and 9205435. We are grateful for assistance with TEM and microprobe analysis by E. Snow and C. Henderson. R. Keller and M. Johnston provided invaluable technical assistance. $K$. Mezger, D. Palais, S. Tommasini and R. Lange provided criticism of early versions of the manuscript. We thank Y. Zhang and B. Watson for discussion and access to their (then) unpublished data. Reviews by Richard Carlson, Jonathan Patchett and Stephen Blake are gratefully acknowledged too.

\section{References}

[1] R.L. Smith, Ash flow magmatism, Geol. Soc. Am. Spec. Pap. 180, 5-26, 1979.

[2] F.J. Spera and J.A. Crisp, Eruption volume, periodicity and caldera area: relationships and inferences on development of compositional zonation in silicic magma chambers, J. Volcanol. Geotherm. Res. 11, 169-187, 1981.

[3] B. Marsh, Magmatic processes, Rev. Geophys. 25, 1043$1053,1987$.

[4] A.N. Halliday, G.A. Mahood, P. Holden, J.M. Metz, T.J. Dempster and J.P. Davidson, Evidence for long residence times of rhyolitic magma in the Long Valley magmatic system: the isotopic record in precaldera lavas of Glass Mountain, Earth Planet. Sci. Lett. 94, 274-290, 1989.

[5] J.N. Christensen and D.J. DePaolo, Timescale of large volume silicic magma systems: $\mathrm{Sr}$ isotopic systematics of phenocrysts and glass from the Bishop Tuff, Long Valley, California, Contrib. Mineral. Petrol. 113, 100-114, 1993.

[6] K.V. Cashman, Textural constraints on the kinetics of crystallization of igneous rocks, in: Modern Methods of Igneous Petrology, J. Nicholls and J.K. Russell, eds., Mineral. Soc. Am. Spec. Publ. 24, 259-314, 1991.

[7] J.M. Metz and G.A. Mahood, Precursors to the Bishop Tuff eruption, Glass Mountain, Long Valley, California, J. Geophys. Res. 90, 11121-11126, 1985.

[8] J.M. Metz and G.A. Mahood, Development of the Long Valley, California magma chamber recorded in precaldera rhyolite lavas of Glass Mountain, Contrib. Mineral. Petrol. 106, 379-397, 1991.

[9] A.N. Halliday, A.E. Fallick, J. Hutchinson and W. Hildreth, $\mathrm{A} \mathrm{Nd}, \mathrm{Sr}$ and $\mathrm{O}$ isotopic investigation into the 
causes of chemical and isotopic zonation in the Bishop Tuff, California. Earth Planet. Sci. Lett. 68, 379-391, 1984.

[10] R.S.J. Sparks, H.E. Huppert and C.J.N. Wilson, Comment on 'Evidence for long residence times of rhyolitic magma in the Long Valley magmatic system: the isotopic record in precaldera lavas of Glass Mountain' by Halliday A.N., Mahood G.A., Holden P., Metz J.M., Dempster, T.J. and Davidson J.P., Earth Planet. Sci. Lett. 99, 387-389, 1991.

[11] G.A. Mahood, Second reply to comment of Sparks R.S.J., Huppert H.E. and Wilson C.J.N. on 'Evidence for long residence times of rhyolitic magma in the Long Valley magmatic system: the isotopic record in precaldera lavas of Glass Mountain', Earth Planet. Sci. Lett. 99, 395-399, 1991.

[12] A.N. Halliday, Reply to comment of Sparks R.S.J., Huppert H.E. and Wilson C.J.N. on 'Evidence for long residence times of rhyolitic magma in the Long Valley magmatic system: the isotopic record in precaldera lavas of Glass Mountain', Earth Planet. Sci. Lett. 99, 390-394, 1991.

[13] G.R. Davies, unpublished data.

[14] E. Snow, pers. commun.. 1991.

[15] Ph. Lo Bello, G. Féraud, C.M. Hall, D. York, P. Lavina and $\mathrm{M}$. Bernat, ${ }^{40} \mathrm{Ar}-{ }^{39} \mathrm{Ar}$ step-heating and laser fusion dating of Quaternary volcanics from Neschers, Massif Central, France: The defeat of xenocrystal contamination, Chem. Geol. (Isot. Geosci. Sect.), 66, 61-71, 1987.

[16] C.M. Gilbert, M.N. Christensen, Y. Al-Rawi and K.R. Lajoie, Structural and volcanic History of Mono Basin, California-Nevada, Geol. Soc. Am. Mem. 116, 275-329, 1968.

[17] D.J. DePaolo, A neodynium and strontium isotopic study of the Mesozoic calc-alkaline granitic batholith of the Sierra Nevada and Peninsular ranges, California, J. Geophys. Res. 86, 10470-10488, 1981.

[18] R.A. Bailey, Geological map of the Long Valley caldera, Mono-Inyo-Craters volcanic chain, and vicinity, eastern California, U.S. Geol. Surv. Map I-1933, 1989.

[19] W.D. Sharp, Pre-Cretaceous crustal evolution in the Sierra Nevada region of California, in: Metamorphism and Crustal Evolution of the western United States, Rubey Vol. VII, W.G. Ernst, ed., pp. 823-864, PrenticeHall, 1988.

[20] B.R. Doe and M.H. Delevaux, Variations in the lead-isotopic compositions in Mesozoic granitic rocks of California-a preliminary investigation, Geol. Soc. Am. Bull. 84, 3513-3526, 1973.

[21] M.A. Domenick, R.W. Kistler, F.C.W. Dodge and M. Tatsumoto, $\mathrm{Nd}$ and $\mathrm{Sr}$ isotopic study of crustal and mantle inclusions from the Sierra Nevada xenoliths and implications for batholith petrogenesis, Geol. Soc. Am. Bull. 94, 713-719, 1983.

[22] J.B. Saleeby et al,, Corridor C-2, Central California offshore to Colorado plateau, centennial continent-ocean transect 10, Geol. Soc. Am., 1986.

[23] J.L. Wooden, J.S. Stacey, K.A. Howard, B.R. Doe and
D.M. Miller, $\mathrm{Pb}$ isotopic evidence for the formation of Proterozoic crust in the southwestern United States, in: Metamorphism and Crustal Evolution of the western United States, Rubey Vol. VII, W.G. Ernst, ed., pp. 68-86, Prentice-Hall, 1988.

[24] E.B. Watson and D.J. Cherniak, Diffusion of strontium and rubidium in K-feldspar measured by Rutherford backscattering spectroscopy, EOS 72(17), 309, 1991.

[25] B.J. Giletti, Rb and Sr diffusion in alkali feldspar, with implications for cooling histories of rocks, Geochim. Cosmochim. Acta 55, 1331-1343, 1991.

[26] D.J. Cherniak and E.B. Watson, A study of strontium diffusion in K-feldspar, Na-K-feldspar and anorthite using Rutherford Backscattering Spectroscopy, Earth Planet. Sci. Lett. 113, 411-425, 1992.

[27] D.R. Baker, Tracer versus trace element diffusion: Diffusional decoupling of $\mathrm{Sr}$ concentration from $\mathrm{Sr}$ isotope composition, Geochim. Cosmochim. Acta 53, 3015-3023, 1989.

[28] S. van der Laan, Y. Xhang, A.K. Kennedy and P.J. Wyllie, Comparison of element and isotope diffusion of $\mathrm{K}$ and $\mathrm{Ca}$ in multicomponent silicate melts, Earth Planet. Sci. Lett. 123, 155-166, 1994.

[29] W. Hildreth, The Bishop Tuff: evidence for the origin of compositional zonation in silicic magma chambers, Geol Soc. Am. Spec. Pap., 180, 43-75, 1979.

[30] J. Crank, The Mathematics of Diffusion. Oxford University Press, 1975.

[31] A.N. Halliday, J.P. Davidson, W. Hildreth and P. Holden, Modelling the petrogenesis of high $\mathrm{Rb} / \mathrm{Sr}$ silicic magmas, Chem. Geol. 92, 107-114, 1991.

[32] E.B. Watson, T.M. Harrison and F.J. Ryerson, Diffusion of $\mathrm{Sm}, \mathrm{Sr}$ and $\mathrm{Pb}$ in fluorapatite, Geochim. Cosmochim. Acta 49, 1813-1823, 1985.

[33] J.R. Farver and B.J. Giletti, Oxygen and strontium diffusion kinetics in apatite and potential applications to thermal history determinations, Geochim. Cosmochim. Acta 53, 1621-1631, 1991.

[34] D.J. Cherniak and F.J. Ryerson, A study of strontium diffusion in apatite using Rutherford backscattering spectroscopy and ion implantation, Geochim. Cosmochim. Acta 57, 4653-4662, 1993.

[35] A.W. Hofmann, B.J. Giletti, J.R. Hinthorne, C.A. Anderson and D. Comaford, Ion microprobe analysis of a potassium self-diffusion experiment in biotite, Earth Planet. Sci. Lett. 24, 48-52, 1974.

[36] B.J. Giletti, Diffusion kinetics of $\mathrm{Mg}, \mathrm{Ca}, \mathrm{Sr}$ and $\mathrm{Ba}$ in albite and $\mathrm{Sr}$ in muscovite and biotite, EOS 72(44), 528, 1991.

[37] G.R. Davies, A.N. Halliday and G.A. Mahood, The crystallization ages of minerals from a silicic magma chamber, in: Proc. ICOG 7, p. 25, Geol. Soc. Aust. 27, 1990.

[38] H.R. Shaw, Links between magma-tectonic rate balances, plutonism and volcanism, J. Geophys. Res. 90, 11275-11288, 1985.

[39] J.M. Metz and R.A. Bailey, Geologic map of Glass Mountain, Long Valley, California, U.S. Geol. Surv. Map. I-1995. 